\title{
DIFFERENCES BETWEEN 100-METER AND 25-METER DIGITAL ELEVATION MODELS ACCORDING TO TYPES OF RELIEF IN SLOVENIA
}

RAZLIKE MED STOMETRSKIM IN PETINDVAJSETMETRSKIM DIGITALNIM MODELOM VISIN GLEDE NA TIPE RELIEFA V SLOVENIJI

Mauro Hrvatin, Drago Perko

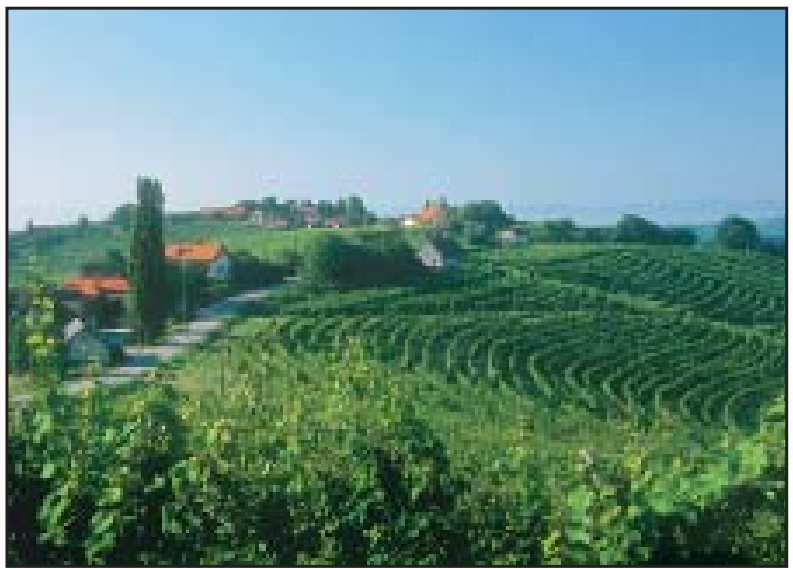

Undulating low hills in the vicinity of Jeruzalem in Slovenske Gorice, northeastern Slovenia (photograph: Mimi Urbanc). Razgibano gričevje v okolici Jeruzalema v Slovenskih goricah, severovzhodna Slovenija (fotografija: Mimi Urbanc).

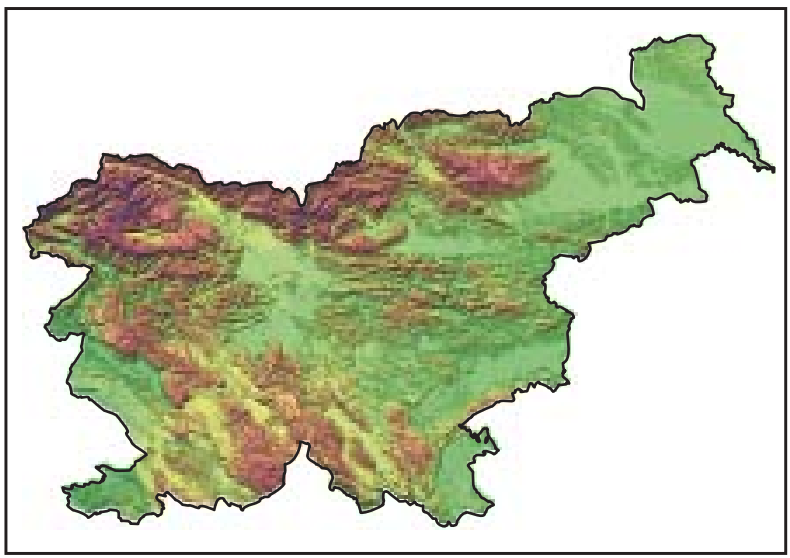




\section{Differences between 100-meter and 25-meter digital elevation models according to types of relief in Slovenia}

UDC: 551.43:004.9(497.4)

COBISS: 1.01

ABSTRACT: Studying relief and landscapes, we often employ digital elevation models. Their applicability is primarily linked to their accuracy. In this paper, we compare the older 100-meter digital elevation model of Slovenia and the more recent 25-meter digital elevation model. We assess applicability relative to differences in surface heights, surface slopes, and surface aspects for all of Slovenia and for four areas with different relief. We compare the frequency of distribution, arithmetic mean, standard deviation, range, and the coefficient of variation. The statistical analysis of the two digital elevation models of Slovenia indicates that the smallest differences exist relative to surface heights, there are larger differences relative to surface aspects, and the largest differences exist relative to surface slopes.

KEYWORDS: relief, surface, digital elevation model, height, slope, aspect, Slovenia.

The article was submitted for publication on January 27, 2005.

ADDRESSES:

Mauro Hrvatin, B. Sc.

Anton Melik Geographical Institute

Scientific Research Centre of the Slovenian Academy of Sciences and Arts

Gosposka ulica 13, SI - 1000 Ljubljana, Slovenia

E-mail:mauro@zrc-sazu.si

Drago Perko, Ph. D.

Anton Melik Geographical Institute

Scientific Research Centre of the Slovenian Academy of Sciences and Arts

Gosposka ulica 13, SI - 1000 Ljubljana, Slovenia

E-mail:drago@zrc-sazu.si

\section{Contents}

1 Introduction $\quad 10$

2 Selected areas $\quad 11$

3 Surface height 15

4 Surface slope $\quad 15$

5 Surface aspect 16

6 Conclusion 22

7 References 23 


\section{Introduction}

Among all landscape elements, relief contributes the most to the external appearance of Slovenia's landscapes (Hrvatin and Perko 2002, 2003). Given the rapid development of geographical information systems, its visual presentation or the digital elevation model is almost indispensable in modern geographical research.

The applicability of digital elevation models for studying relief and landscape is primarily linked to their accuracy. Until the end of the 1990's, we in Slovenia had only 500-meter and 100-meter digital elevation models of the country's entire territory at our disposal. Both are based on the points of the square grid of the Gauß-Krüger coordinate system (Rihtaršič and Fras 1991). It is understandable that Slovene geographers mainly used the more accurate of the two models, the 100-meter digital elevation model, in their studies as did cartographers in creating thematic maps. The model is composed of data on altitude points that are 100 meters apart from north to south and from east to west, with the corners of the square cells having a 100-meter baseline, a 141-meter diagonal, and an area of one hectare (Perko 2001).

The distance between the points, however, limits the model's applicability since relief features that are not substantially larger than 100 or 141 meters are completely lost or at least somewhat deformed. This failing is particularly significant in studies of landscapes with numerous small relief forms, such as those characteristic of the karst relief that covers almost one half of Slovenia.

In 2000, we at the Scientific Research Center of the Slovenian Academy of Sciences and Arts created a 25-meter digital elevation model from radar pictures taken by the European Space Agency between 1995 and 1999 called the "InSAR DEM 25 radar interferometry digital elevation model " (Podobnikar and Oštir 1999; Oštir, Podobnikar, Stančič, and Mlinar 2000; Podobnikar 2002; Podobnikar 2005). The model is composed of data on altitude points that are 25 meters apart from north to south and from east to west, with the corners of the square cells having a 25-meter baseline, a 35-meter diagonal, and an area of $625 \mathrm{~m}^{2}$.

Testing proved that the accuracy of the 100-meter digital elevation model is approximately 10 meters ( 3 meters for plains and 16 meters for mountains), while the accuracy of the 25-meter digital elevation model is approximately 5 meters ( 2 meters for plains and 14 meters for mountains); in both cases, the roughest errors in a few examples in the Alps exceeded 50 meters (Državna geodezija 1998, Digitalni modeli višin 2004).

The ratio between the distance of the points in the 100 -meter and the 25 -meter digital elevation models is $4: 1$, and between the surface area of the square cells, $16: 1$. In this sense, the 25 -meter digital elevation model is sixteen times more accurate that the 100-meter model.

Of the three basic geometric properties of planes that we can establish in the framework of the geographical information system using a digital elevation model, that is, distance, inclination, and curvature relative to horizontal and vertical (Perko 2002), we selected the three properties or indicators for comparison that are the most frequently used in geography. These are:

- surface height or the distance of surface relative to the horizontal,

- surface slope or the inclination of surface relative to the horizontal, and

- surface aspect or the inclination of surface relative to the vertical.

Surface height is given in meters, surface slope in degrees from 0 for level surfaces to 90 for vertical surfaces, and surface aspect in degrees from 0 for north facing sites to 180 for south facing sites. We calculated these indicators for all of Slovenia and for four areas with different relief (rectangular sections) each nine kilometers long and six kilometers wide with a surface area of $54 \mathrm{~km}^{2}$. For calculating the indicators, we used the IDRISI program package (Eastman 1995). 
The established indicators from the 100-meter digital elevation model are based on 2,027,198 data items for all of Slovenia and on 5,400 data items for the individual areas, while those from the 25-meter digital elevation model are based on 32,436,693 data items for all of Slovenia and 86,400 data items for the individual areas. The areas (Figure 1), which we named after Mount Škrlatica in the Julian Alps, the Mirna River, a tributary of the Sava River, and the villages of Jeruzalem in Slovenske Gorice and Śkocjan near the Škocjan Caves, are described briefly in Chapter 2.

The following three chapters present the results of comparisons between the 25-meter and 100-meter digital elevation models of Slovenia and the selected areas relative to surface height, surface slope, and surface aspect. We compare the frequency of distribution, arithmetic mean, standard deviation, range (difference between highest and lowest values), and the coefficient of variation (ratio between standard deviation and arithmetic mean) and test the arithmetic means of surface heights, surface slopes, and surface aspects.

Hereafter, »DEM-100« refers to the 100-meter digital elevation model and »DEM-25« to the 25-meter digital elevation model.

\section{Selected areas}

The areas we selected for the comparison of DEM-100 and DEM-25 differ primarily relative to the morphological and genetic type of relief, the vertical and horizontal surface roughness, and the rock structure (Figure 1).

The Mount Škrlatica area (Figure 2) lies in the northern part of the eastern Julian Alps and includes the Škrlatica and Martuljek mountains that rise above the tree line and substantially surpass 2,000 meters in altitude. To the north this imposing mountain group is bordered by the Sava River valley, to the west by the valley of the Velika Pišnica River, and on the east by the Vrata valley. The mountains are largely composed of carbonate rock, mostly thick layers of limestone, and the valleys are filled with glacial and river sediments. In the landscapes heavily transformed by glacial action, precipitous hillslopes that descend from peak ridges into deep cirques stand out (Mihelič 2003). Large vertical and small horizontal surface roughness is characteristic of the area (Perko 2002).

The Mirna River area (Figure 3) covers the hills and to a smaller extent the low hills of the lower watershed of the Mirna River between the settlement of Tržišče and its confluence with the Sava River. In this section, the Mirna River cuts through the ridge that links the hills around Boštanj and Krško. The river carved a deep gorge, and its entrenched meanders are especially interesting. The fluviodenudational surface composed mostly of marl and dolomite rock is extremely dissected, the ridges are quite branched, and the hillslopes are smooth without any ravines (Topole 1998). Moderate vertical and horizontal surface roughness is characteristic of the area (Perko 2002).

The Jeruzalem area (Figure 4) covers part of the low Ljutomersko-Ormoške hills in eastern Slovenske Gorice. Their backbone is the marl and sandstone ridge dividing the watersheds of the Ščavnica and Drava rivers. The divide ridge runs east to west, and numerous side spurs run mainly north and south (Kert 1991). In the impermeable and easily erodible rock, streams have carved numerous ravines and small valleys that are often moist due to the modest gradient. Landslides are periodically triggered on the steeper slopes (Belec 1968). Moderate vertical and large horizontal surface roughness is characteristic of the area (Perko 2002).

The Škocjan area (Figure 5) is located in the southeastern part of the Divača karst region and covers the wider vicinity of the Śkocjan Caves. This karst plateau is roughly level and boasts numerous dolines and deep collapse dolines that formed above the former and current underground courses of the Reka River. Many streams flow in from the northern foothills of the flysch Brkini region: several flow into the Reka River on the surface while others sink in the gables of blind valleys. The picturesque canyon and the large blind valley at the entrance to the Škocjan Caves were created by the Reka River (Mihevc 2001). Small vertical and moderate horizontal surface roughness is characteristic of the area (Perko 2002). 
Acta geographica Slovenica, 45-1, 2005

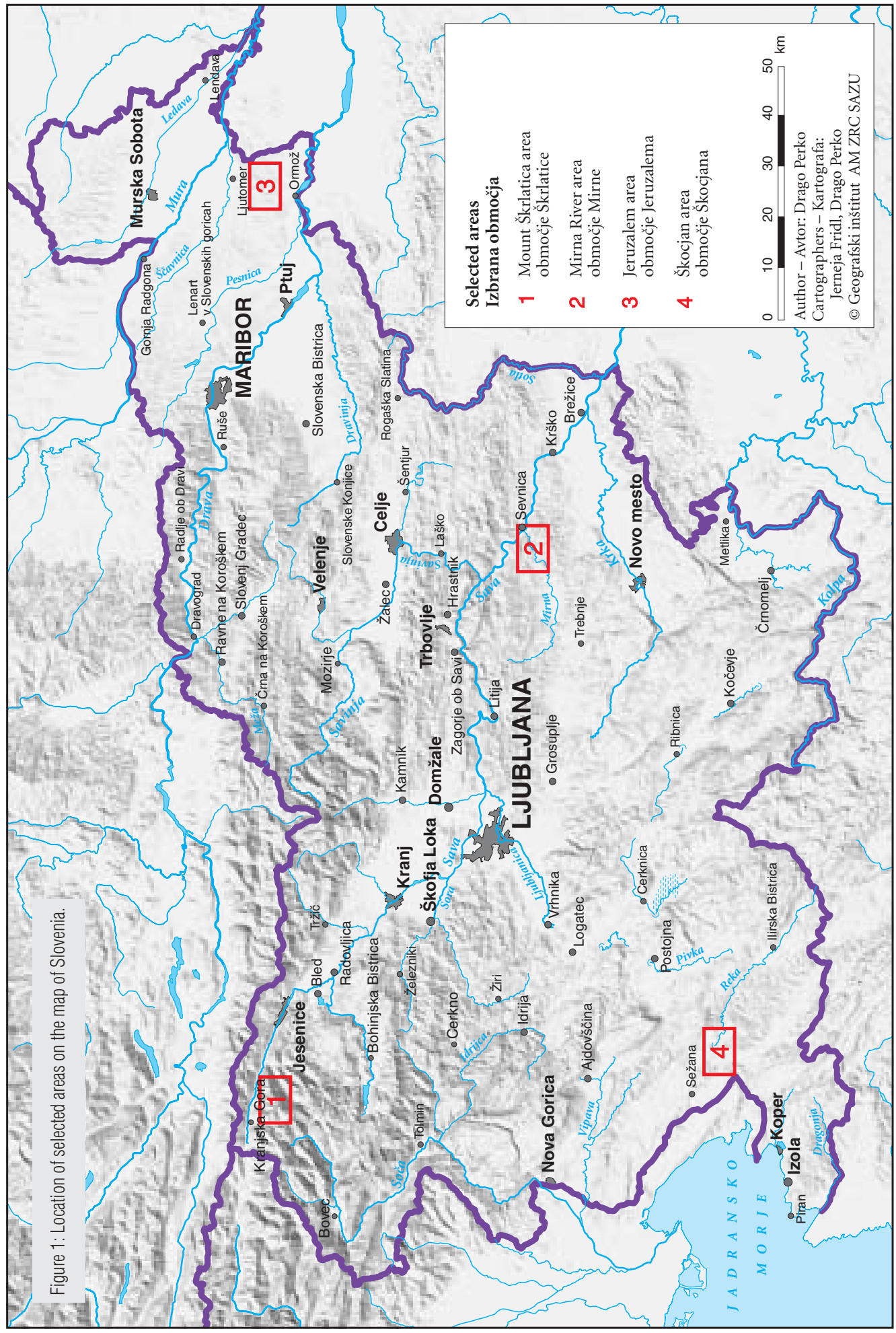




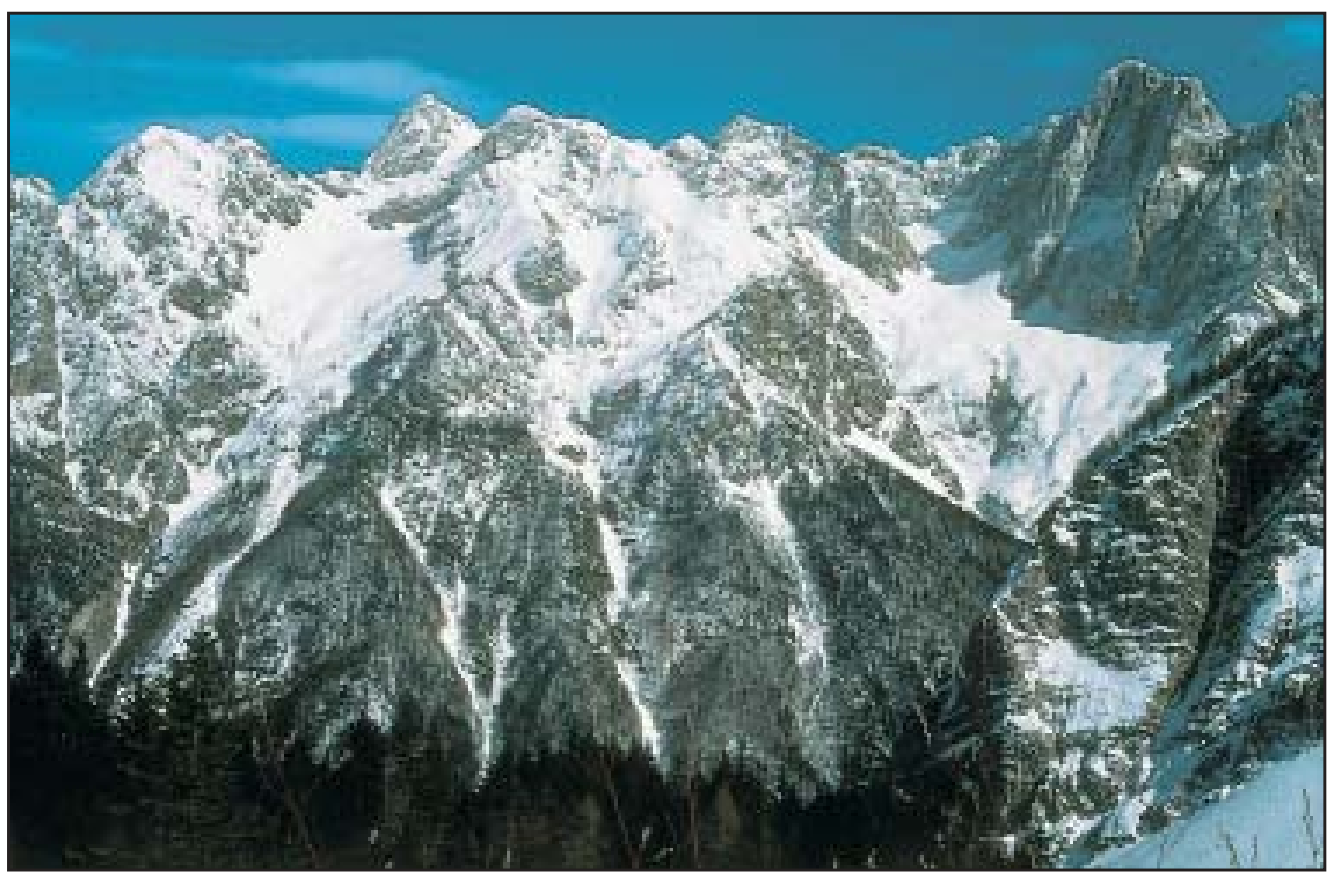

Figure 2: Škrlatica mountain group (2,740 m) in the eastern part of the Julian Alps (photograph: Miha Pavšek).

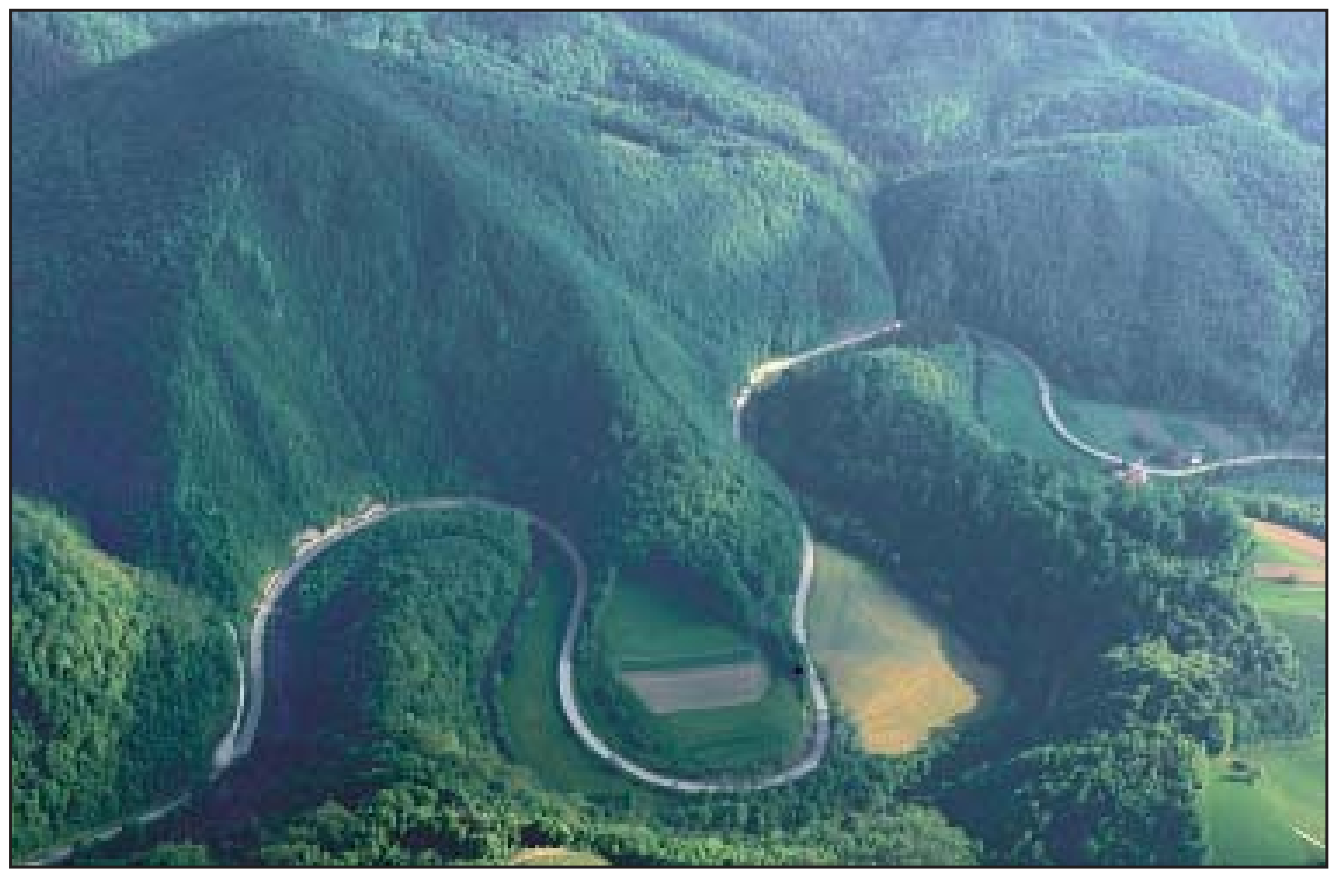

Figure 3: Picturesque entrenched meanders of the Mirna River in the low Krško mountains (photograph: Marko Kapus). 


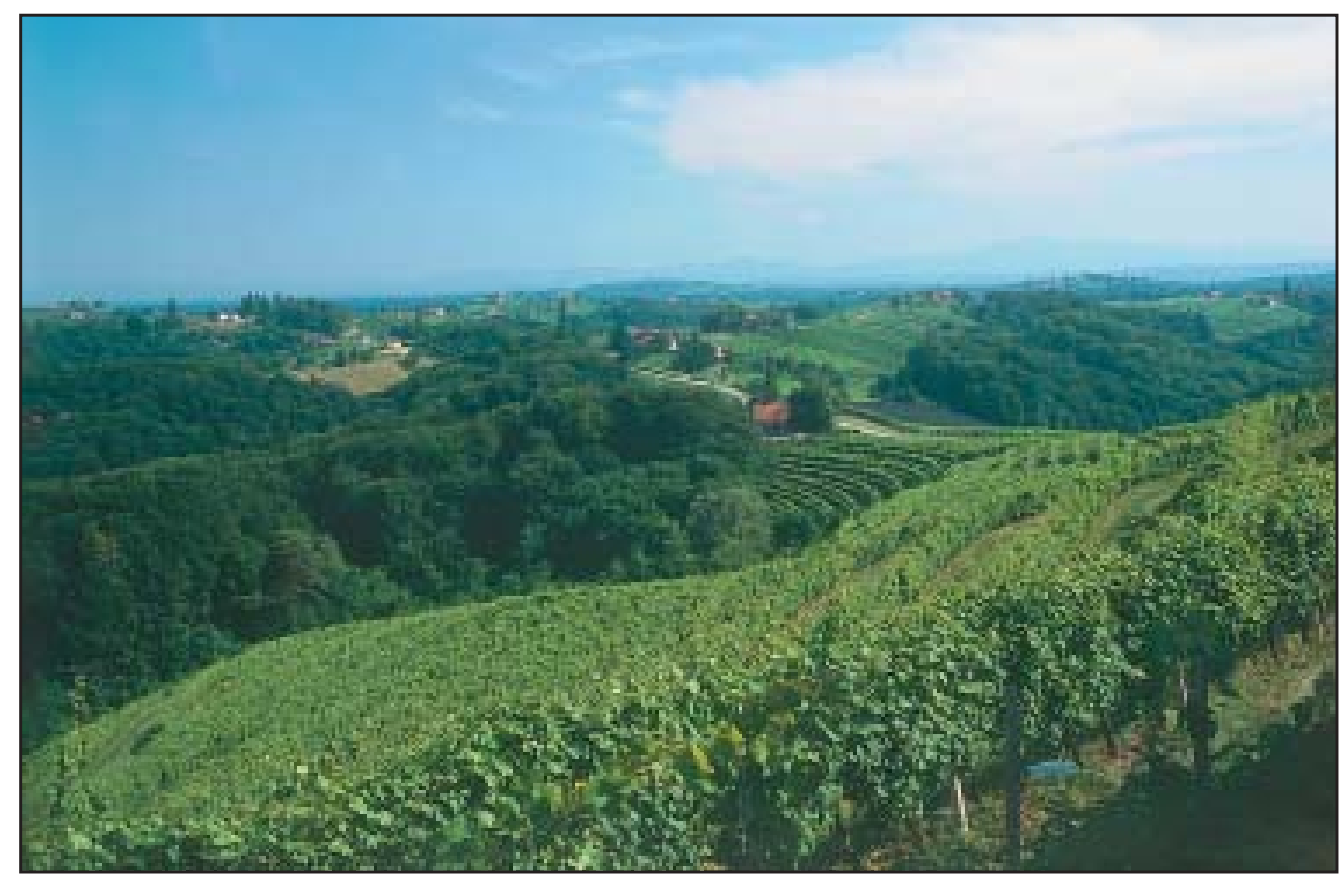

Figure 4: Ridges of the Jeruzalem hills near Vinski Vrh (photograph: Mimi Urbanc).

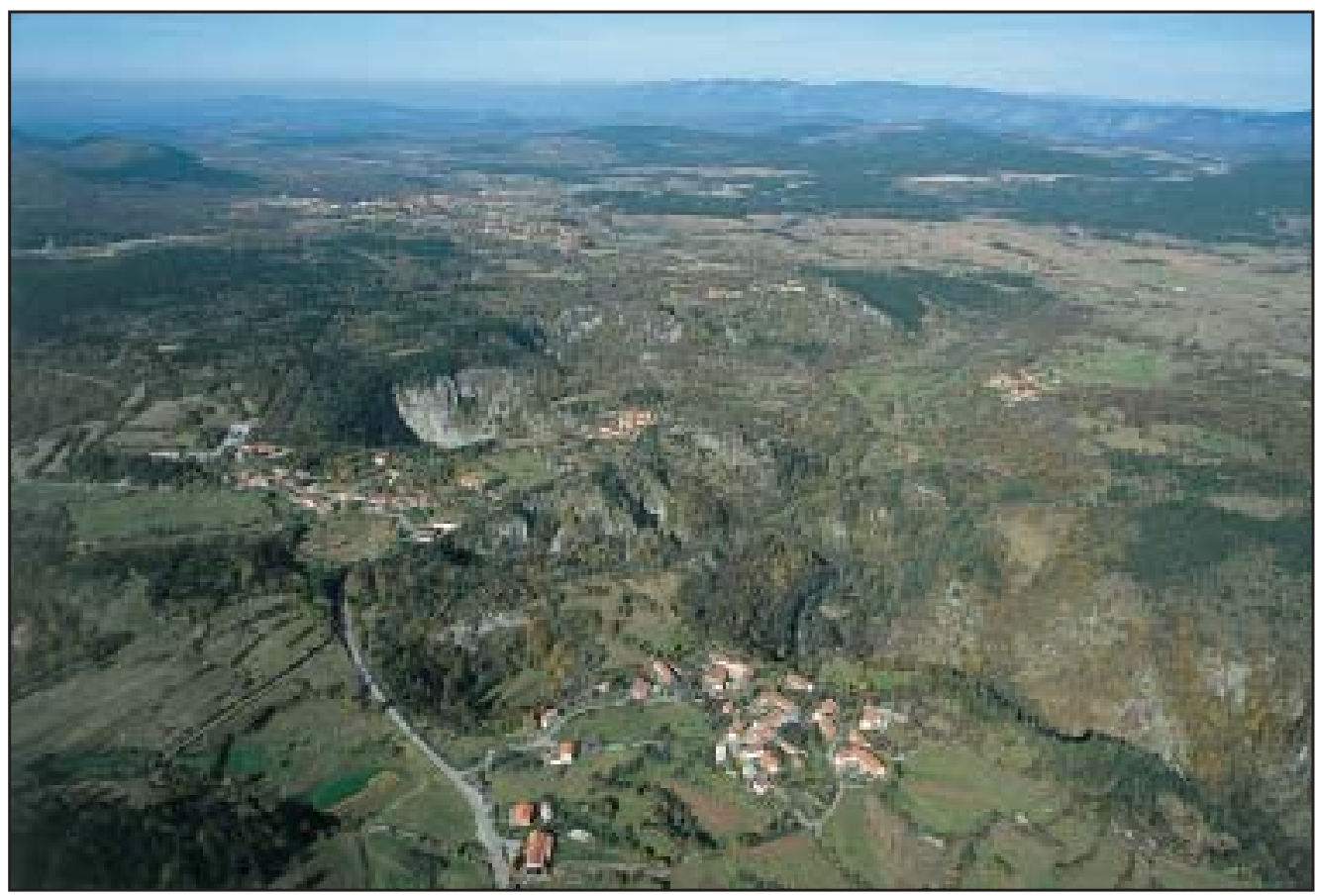

Figure 5: Karst surface with collapse dolines in the vicinity of Škocjan (photograph: Marjan Grbajs). 


\section{Surface heights}

The curves of the frequency distribution of surface heights in DEM-25 and DEM-100 for both Slovenia and the selected areas overlap over almost their entire length.

The differences in the average surface heights between DEM-25 and DEM-100 are only $0.56 \mathrm{~m}$ for Slovenia, $2.46 \mathrm{~m}$ for the Mount Škrlatica area, $1.76 \mathrm{~m}$ for the Mirna River area, $0.83 \mathrm{~m}$ for the Jeruzalem area, and $0.18 \mathrm{~m}$ for the Škocjan area. For the standard deviation of surface heights, the differences are $0.79 \mathrm{~m}$ for Slovenia, $1.64 \mathrm{~m}$ for the Mount Škrlatica area, $1.45 \mathrm{~m}$ for the Mirna River area, $1.95 \mathrm{~m}$ for the Jeruzalem area, and $0.75 \mathrm{~m}$ for the Škocjan area. The differences in the coefficients of variation for surface heights between DEM-25 and DEM-100 are barely $0.08 \%$ (percentage point) for Slovenia, $0.15 \%$ for the Mount Škrlatica area, $0.29 \%$ for the Mirna River area, $0.73 \%$ for the Jeruzalem area, and $0.15 \%$ for the Škocjan area with ratios of 1.0012 or $0.12 \%$ for Slovenia, 1.0054 or $0.54 \%$ for the Mount Škrlatica area, 1.0110 or $1.10 \%$ for the Mirna River area, 1.0790 or $7.90 \%$ for the Jeruzalem area, and 1.0105 or $1.05 \%$ for the Škocjan area.

It is understandable that the variability expressed by the coefficient of variation is higher for all of Slovenia than for the selected areas because the range or span of surface height for Slovenia is between 1 and 2,816 meters in DEM-100 and between 0.00 and 2,851.80 meters in DEM-25, while in the Jeruzalem area, where the range is the lowest, it is only between 208 and 332 meters in DEM-100 and between 204.50 and 346.20 meters in DEM-25.

In all the cases, the differences are relatively small, and therefore the use of DEM-100 suffices for calculating basic statistical indicators such as arithmetic means, variance, standard deviation, and coefficients of variation for both the entire area of Slovenia and for smaller sections such as our selected areas.

This is further demonstrated by a comparison of the average surface heights of DEM-100 and DEM-25 using the t-test, which indicated that for Slovenia and the selected areas there are no statistically significant differences given a 99\% confidence level.

We can also establish the differences between DEM-100 and DEM-25 by comparing their graphic representations of surface heights. For example, in the representation of the Jeruzalem area in DEM-100, we can only perceive the course and general formation of valleys and ridges (Figure 18) while DEM-25 reveals their detailed dissection by erosion gullies and ravines (Figure 19).

\section{Surface slope}

The curves of the frequency distribution of surface slopes for all of Slovenia and the selected areas differ substantially in DEM-25 and DEM-100. For all of Slovenia, the DEM-100 curve is higher for surface slopes up to $12^{\circ}$, while the DEM-25 curve is higher for surface slopes from $13^{\circ}$ on. In all of the selected areas, the DEM-100 curve is also higher for lower surface slopes and lower for higher surface slopes. This is understandable because the more accurate DEM-25 can show the variability of the surface more adequately and therefore the higher more extreme surface slopes as well. For example, for the Mirna River area the proportion of cells with a $12^{\circ}$ surface slope is $5.78 \%$ in DEM-100 but only $3.69 \%$ in DEM-25, and the proportion of cells with a $24^{\circ}$ surface slope is only $0.85 \%$ in DEM-100 although as high as $3.10 \%$ in DEM-25. In individual cases, the differences are multiple.

The differences in average surface slopes between DEM-25 and DEM-100 are $3.06^{\circ}$ for all of Slovenia, $2.81^{\circ}$ for the Mount Škrlatica area, $5.31^{\circ}$ for the Mirna River area, $3.38^{\circ}$ for the Jeruzalem area, and $2.20^{\circ}$ for the Škocjan area, and between the standard deviation of surface slopes, $1.83^{\circ}$ for all of Slovenia, $1.38^{\circ}$ for the Mount Škrlatica area, $2.11^{\circ}$ for the Mirna River area, $2.08^{\circ}$ for the Jeruzalem area, and $2.11^{\circ}$ for the Škocjan area. The differences in the coefficients of variation of surface slopes in DEM-25 and DEM-100 are $6.00 \%$ (percentage points) for all of Slovenia, 1.05\% for the Mount Škrlatica area, $4.91 \%$ for the Mirna River area, 3.62\% for the Jeruzalem area, and 6.12\% for the Škocjan area with ratios of 0.9319 or $6.81 \%$ 
for all of Slovenia, 1.0291 or $2.91 \%$ for the Mount Škrlatica area, 0.9118 or $8.82 \%$ for the Mirna River area, 1.0706 or $7.06 \%$ for the Jeruzalem area, and 1.0857 or $8.57 \%$ for the Škocjan area.

As with surface heights, the variability of surface slopes in all of Slovenia is higher than in the selected areas because the range of surface slopes for all of Slovenia is between $0.00^{\circ}$ and $77.21^{\circ}$ in DEM-100 and between $0.00^{\circ}$ and $89.24^{\circ}$ in DEM-25, while in the Jeruzalem area, where the range is the smallest, it is between $0.00^{\circ}$ and $18.15^{\circ}$ in DEM-100 and between $0.00^{\circ}$ and $32.80^{\circ}$ in DEM-25.

In every case, the differences between the calculated statistical indicators are so large that even for all of Slovenia the use of DEM-25 instead of DEM-100 is recommended, and this recommendation applies even more for the smaller areas.

This is further demonstrated by comparing the average surface slope of DEM-100 and DEM-25 using the t-test, which indicated that for Slovenia and the selected areas statistically significant differences exist given a $99 \%$ confidence level.

The large differences between DEM-100 and DEM-25 that we established using statistical indicators are also confirmed by the graphical presentations of surface slopes. For example, the presentation of the Mirna River area on DEM-100 shows the formation of the landscape only approximately (Figure 14), while due to the greater differences between the largest and smallest slopes, smaller forms of fluviodenudational relief are clearly visible on DEM-25 (Figure 19), for example, river meanders and the larger scarps of the river terraces.

\section{Surface aspect}

For all of Slovenia and the selected areas, the curves for the frequency of distribution of surface aspects on DEM-25 and DEM-100 differ more than the curves for the frequency of distribution of surface heights but considerably less than the curves for the frequency of distribution of surface slopes. The path of the surface aspect curve for DEM-25 is similar to the path of the surface aspect curve for DEM-100 but smoothed, indicating that the proportions of individual surface aspects on DEM-25 are more even distributed. This is true for all of Slovenia and for the selected areas. For example, for all of Slovenia the proportion of cells with the southernmost aspect of $180^{\circ}$ is $2.53 \%$ for DEM-100 but only $1.50 \%$ for DEM- 25 . On both digital elevation models, the smallest proportion of cells have an exposition of $64^{\circ}: 0.26 \%$ on DEM-100 and $0.40 \%$ on DEM-25. For DEM-100, the ratio between the two values is almost 10 , while for DEM-25 it is less than 4 .

The differences in the average aspects on DEM-25 and DEM-100 are $2.11^{\circ}$ for all of Slovenia, $1.38^{\circ}$ for the Mount Škrlatica area, $1.05^{\circ}$ for the Mirna River area, $2.20^{\circ}$ for the Jeruzalem area, and $3.87^{\circ}$ for the Škocjan area, while the standard deviations of aspect are $1.24^{\circ}$ for all of Slovenia, $0.18^{\circ}$ for the Mount Škrlatica area, $0.89^{\circ}$ for the Mirna River area, $1.37^{\circ}$ for the Jeruzalem area, and $0.23^{\circ}$ for the Škocjan area. The differences in the coefficients of variation of aspect for DEM-25 and DEM-100 are $0.06 \%$ (percentage points) for all of Slovenia, $1.20 \%$ for the Mount Škrlatica area, $1.68 \%$ for the Mirna River area, $2.44 \%$ for the Jeruzalem area, and $3.10 \%$ for the Škocjan area, while the ratios are 0.9990 or $0.10 \%$ for all of Slovenia, 0.9805 or $1.95 \%$ for the Mount Škrlatica area, 0.9720 or $2.80 \%$ for the Mirna River area, 1.0540 or $5.40 \%$ for the Jeruzalem area, and 0.9507 or $4.93 \%$ for the Škocjan area.

In contrast with surface heights and surface slopes, the variability of surface aspects on DEM-100 and DEM-25 - with the exceprion of the Jeruzalem area - is slightly larger in all the selected areas than for Slovenia as a whole, which is also understandable since the range of surface aspect for all of Slovenia and for all the selected areas is the same, between $0.00^{\circ}$ and $180.00^{\circ}$.

Although the differences between the calculated statistical indicators are smaller than with surface slopes, for both all of Slovenia and the smaller areas, the use of DEM-25 instead of DEM-100 is recommended, especially in hilly and dissected karst areas. 


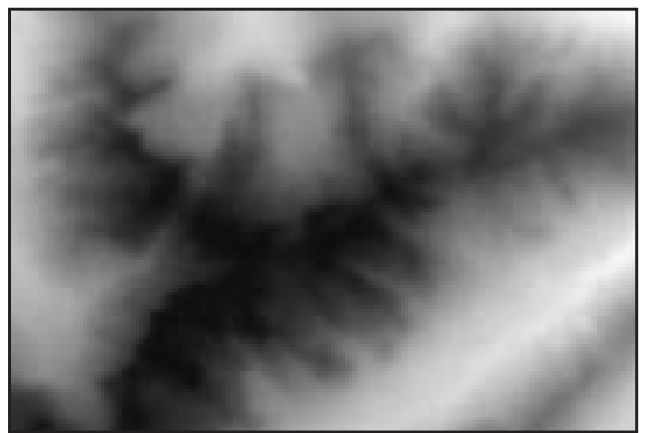

Figure 6: Surface heights of DEM-100 with values between $703 \mathrm{~m}$ (lightest colour) and 2,645 m (darkest colour) for the Mount Śkrlatica area.

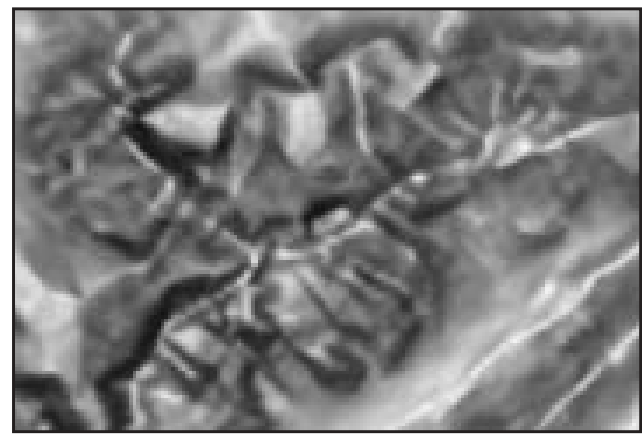

Figure 8: Surface slopes of DEM-100 with values between $0.64^{\circ}$ (lightest colour) and $66.53^{\circ}$ (darkest colour) for the Mount Škrlatica area.

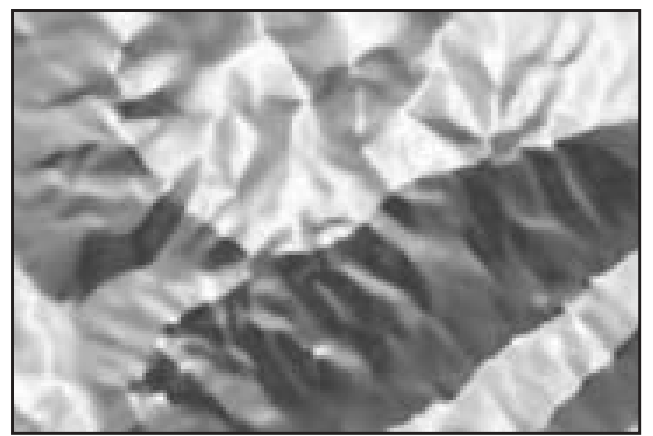

Figure 10: Surface aspects of DEM-100 with values between $0.00^{\circ}$ (lightest colour) and $180.00^{\circ}$ (darkest colour) for the Mount Śkrlatica area.

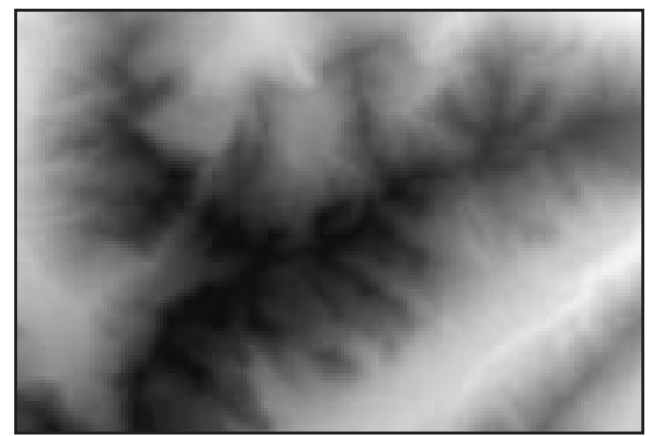

Figure 7: Surface heights of DEM-25 with values between $682.50 \mathrm{~m}$ (lightest colour) and $2718.90 \mathrm{~m}$ (darkest colour) for the Mount Śkrlatica area.

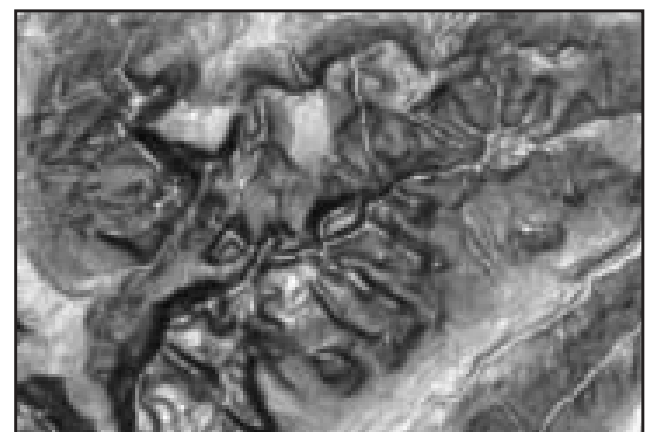

Figure 9: Surface slopes of DEM-25 with values between $0.00^{\circ}$ (lightest colour) and $70.67^{\circ}$ (darkest colour) for the Mount Škrlatica area.

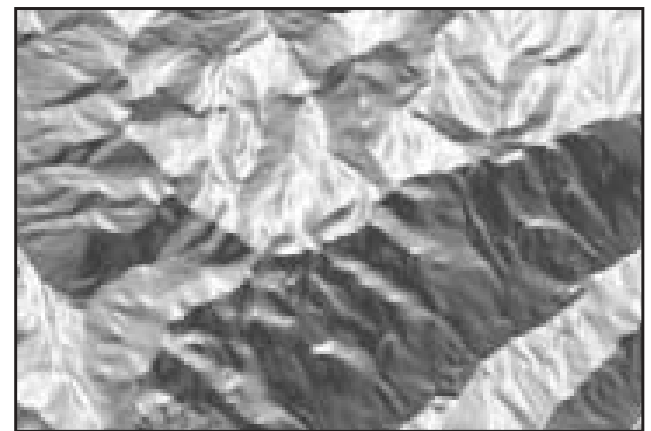

Figure 11: Surface aspects of DEM-25 with values between $0.00^{\circ}$ (lightest colour) and $180.00^{\circ}$ (darkest colour) for the Mount Śkrlatica area. 


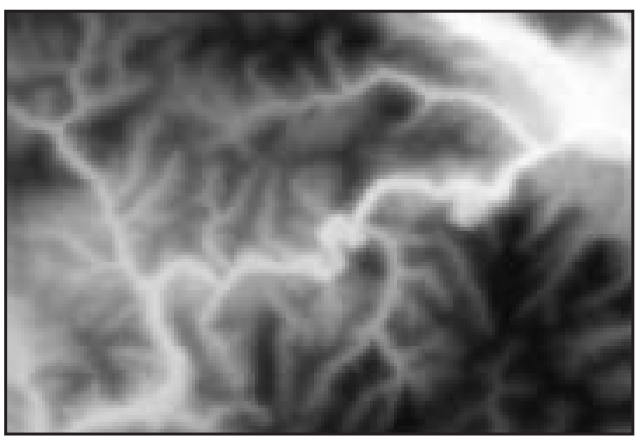

Figure 12: Surface heights of DEM-100 with values between $172 \mathrm{~m}$ (lightest colour) and $577 \mathrm{~m}$ (darkest colour) for the Mirna River area.

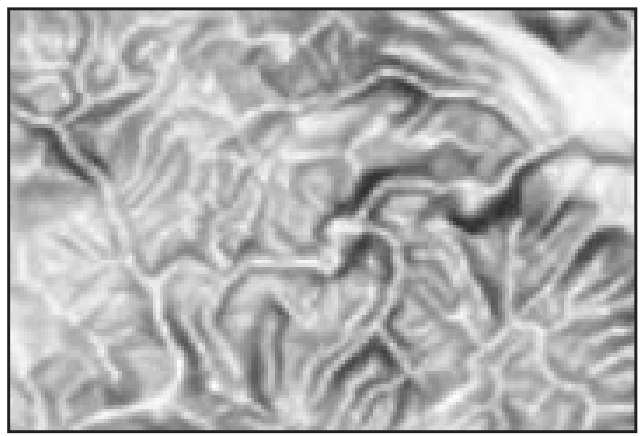

Figure 14: Surface slopes of DEM-100 with values between $0.29^{\circ}$ (lightest colour) and $38.49^{\circ}$ (darkest colour) for the Mirna River area.

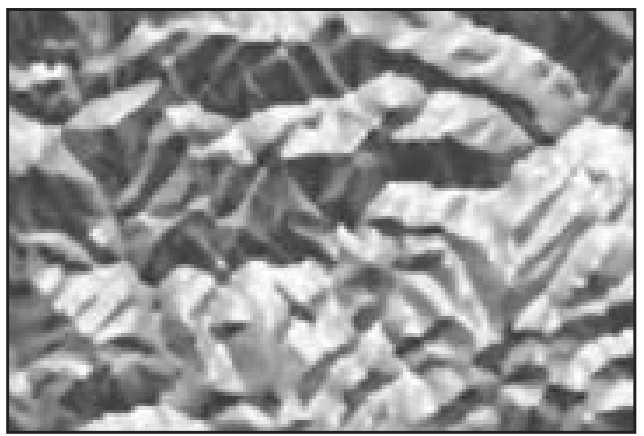

Figure 16: Surface aspects of DEM-100 with values between $0.00^{\circ}$ (lightest colour) and $180.00^{\circ}$ (darkest colour) for the Mirna River area.

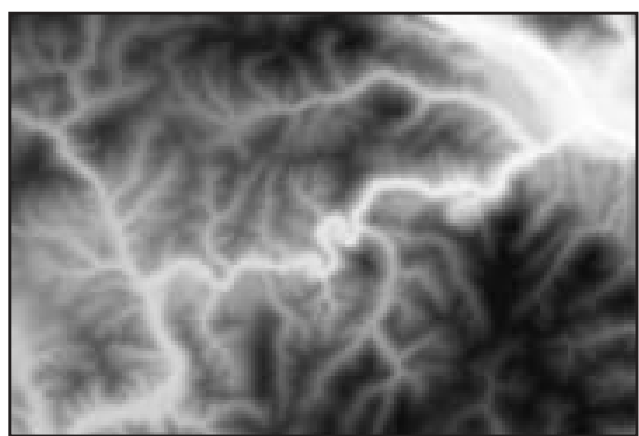

Figure 13: Surface heights of DEM-25 with values between $168.60 \mathrm{~m}$ (lightest colour) and 589,60 $\mathrm{m}$ (darkest colour) for the Mirna River area.

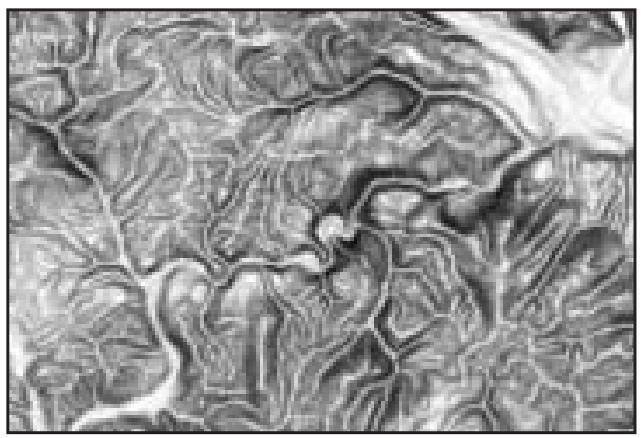

Figure 15: Surface slopes of DEM-25 with values between $0.00^{\circ}$ (lightest colour) and $48.65^{\circ}$ (darkest colour) for the Mirna River area.

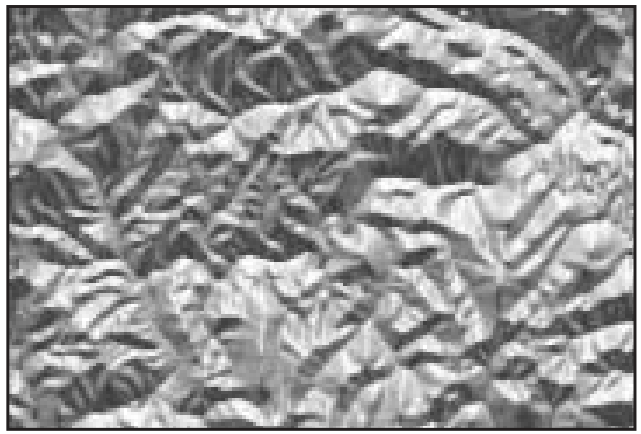

Figure 17: Surface aspects of DEM-25 with values between $0.00^{\circ}$ (lightest colour) and $180.00^{\circ}$ (darkest colour) for the Mirna River area. 


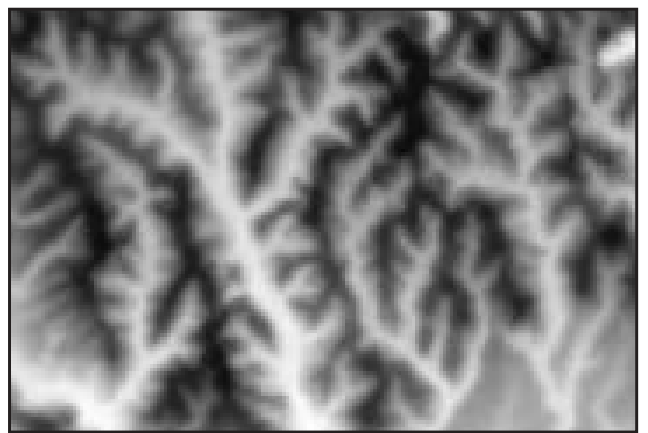

Figure 18: Surface heights of DEM-100 with values between $208 \mathrm{~m}$ (lightest colour) and $332 \mathrm{~m}$ (darkest colour) for the Jeruzalem area.

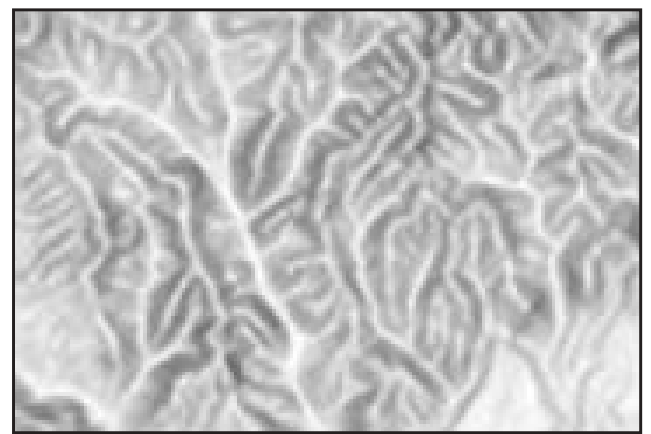

Figure 20: Surface slopes of DEM-100 with values between $0.00^{\circ}$ (lightest colour) and $18.15^{\circ}$ (darkest colour) for the Jeruzalem area.

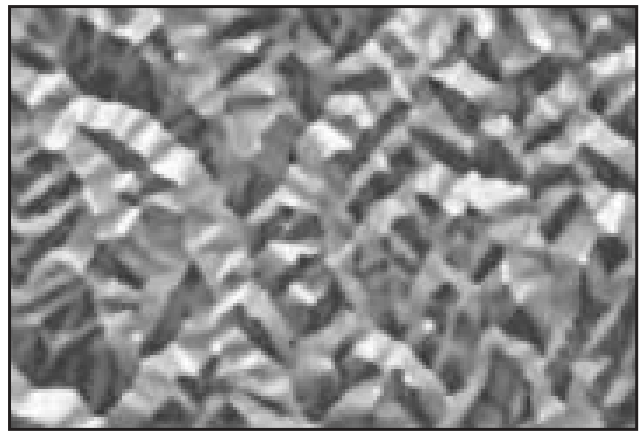

Figure 22: Surface aspects of DEM-100 with values between $0.00^{\circ}$ (lightest colour) and $180.00^{\circ}$ (darkest colour) for the Jeruzalem area.

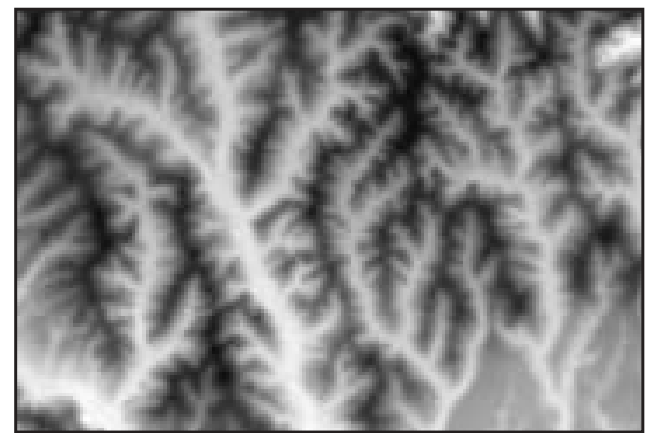

Figure 19: Surface heights of DEM-25 with values between $204.50 \mathrm{~m}$ (lightest colour) and $346.20 \mathrm{~m}$ (darkest colour) for the Jeruzalem area.

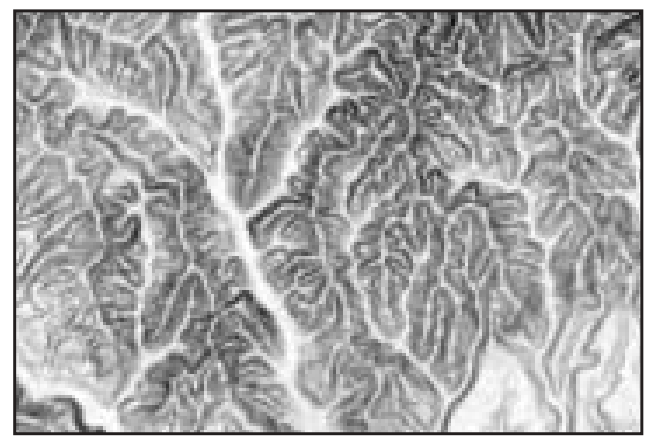

Figure 21: Surface slopes of DEM-25 with values between $0.00^{\circ}$ (lightest colour) and $32.80^{\circ}$ (darkest colour) for the Jeruzalem area.

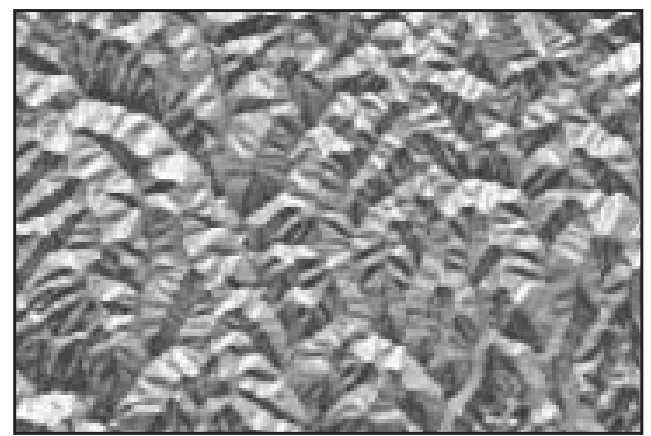

Figure 23: Surface aspects of DEM-25 with values between $0.00^{\circ}$ (lightest colour) and $180.00^{\circ}$ (darkest colour) for the Jeruzalem area. 


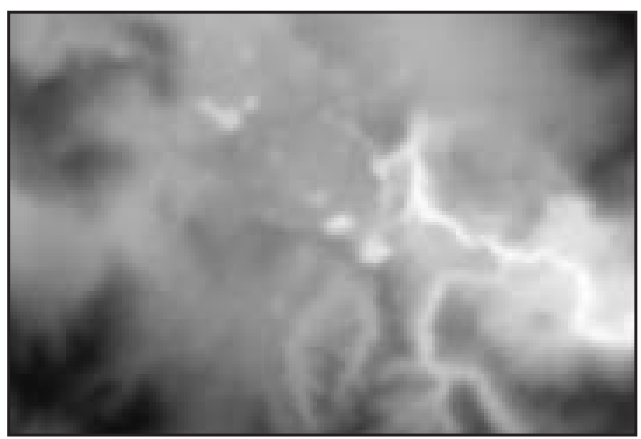

Figure 24: Surface heights of DEM-100 with values between $334 \mathrm{~m}$ (lightest colour) and $750 \mathrm{~m}$ (darkest colour) for the Škocjan area.

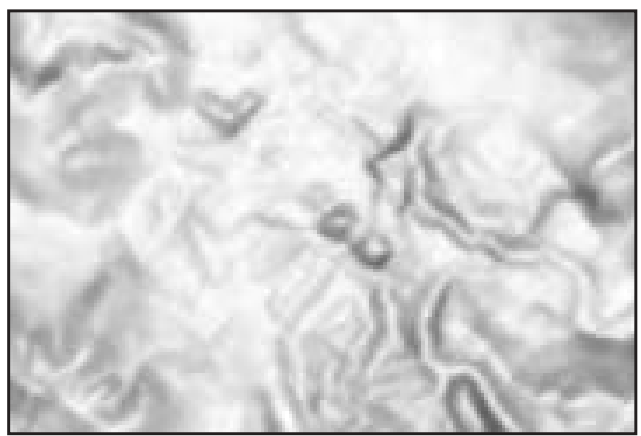

Figure 26: Surface slopes of DEM-100 with values between $0.00^{\circ}$ (lightest colour) and $29.80^{\circ}$ (darkest colour) for the Škocjan area.

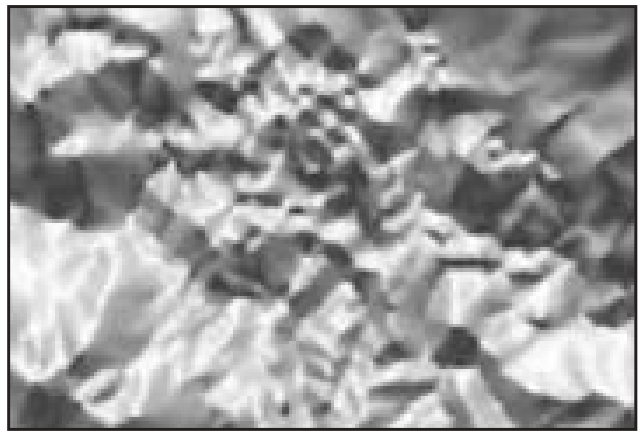

Figure 28: Surface aspects of DEM-100 with values between $0.00^{\circ}$ (lightest colour) and $180.00^{\circ}$ (darkest colour) for the Škocjan area.

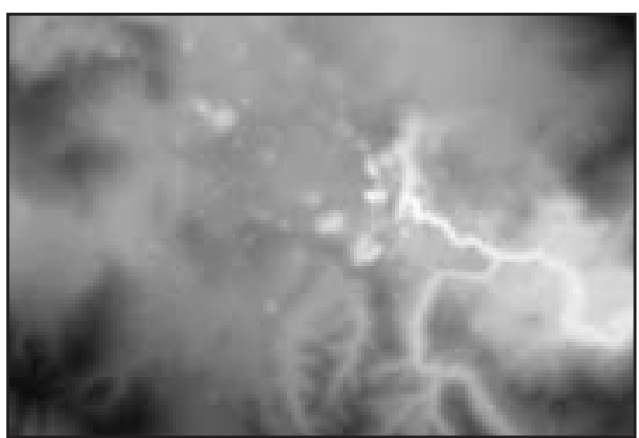

Figure 25: Surface heights of DEM-25 with values between $315.40 \mathrm{~m}$ (lightest colour) and $770.40 \mathrm{~m}$ (darkest colour) for the Škocjan area.

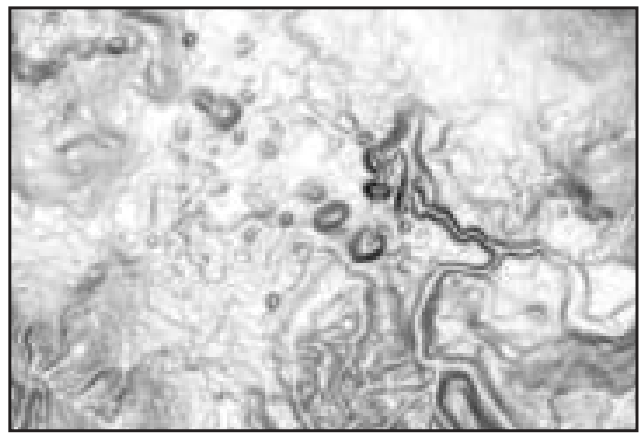

Figure 27: Surface slopes of DEM-25 with values between $0.00^{\circ}$ (lightest colour) and $52.82^{\circ}$ (darkest colour) for the Škocjan area.

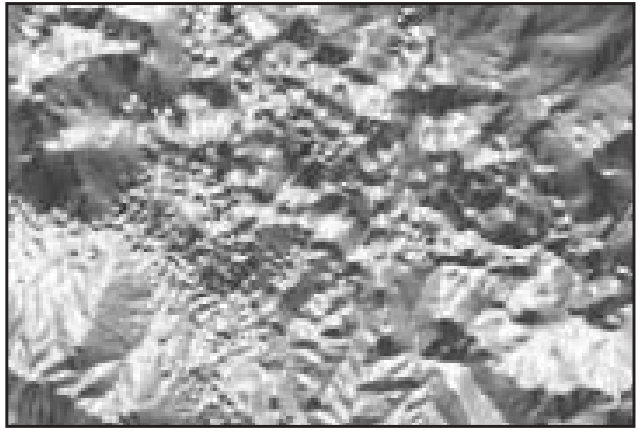

Figure 29: Surface aspects of DEM-25 with values between $0.00^{\circ}$ (lightest colour) and $180.00^{\circ}$ (darkest colour) for the Škocjan area. 


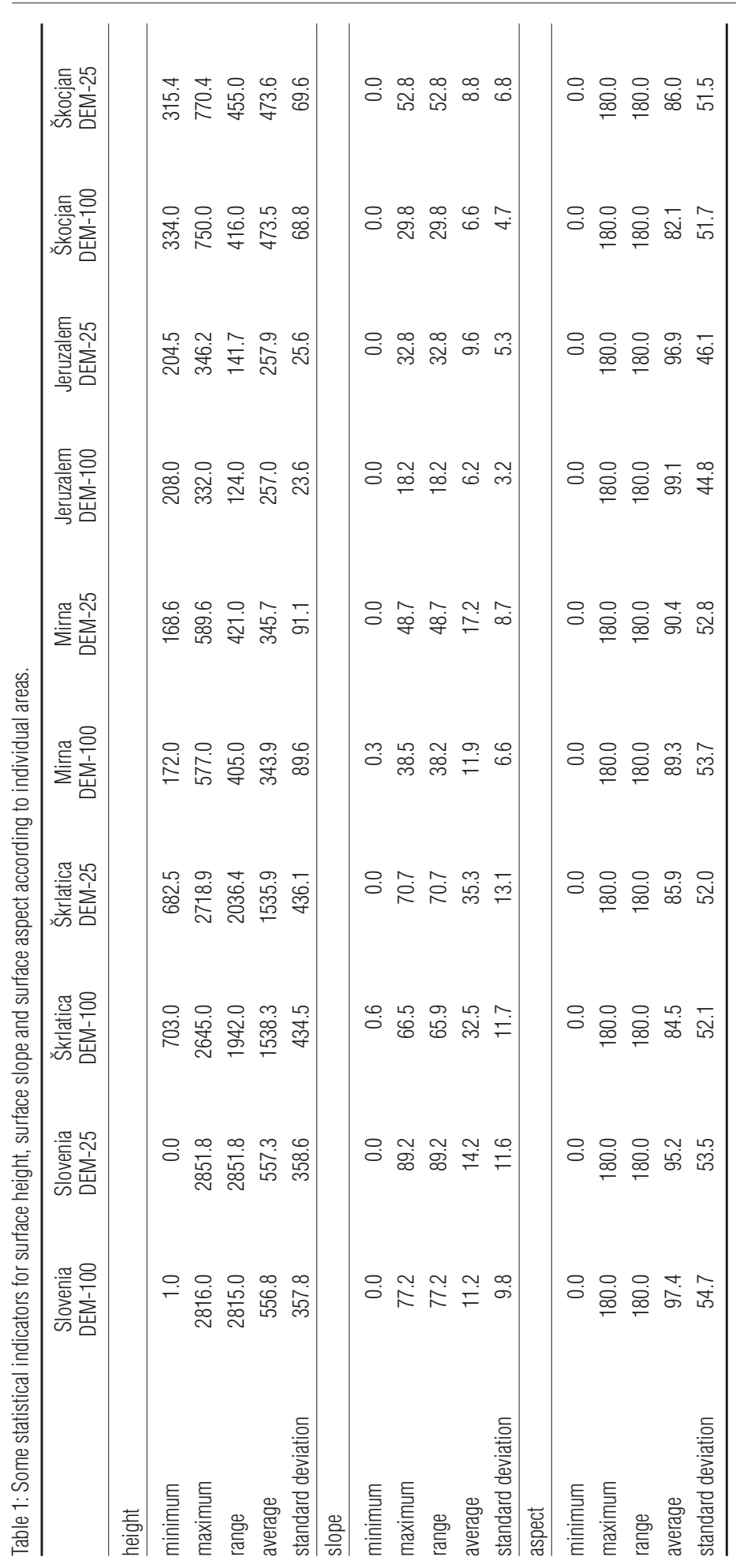


This is further demonstrated by comparing the average surface aspects of DEM-100 and DEM-25 using the t-test, which indicated that the differences for all of Slovenia and the Jeruzalem and Škocjan areas are statistically significant given a 99\% confidence level while those for the Mount Škrlatica and Mirna River areas are not.

In graphical presentations, the differences between aspect in DEM-100 and DEM-25 are most visible on smaller relief forms. For example, in the presentation of the Škocjan area, it is almost impossible to distinguish the formation of the surface on DEM-100 (Figure 28), while on DEM-25, minor variations in the karst surface with its numerous dolines and collapse dolines are clearly visible (Figure 29).

\section{Conclusion}

Studies of relief and landscape using digital elevation models depend greatly on the accuracy of the models. In this article, we describe the 100-meter and 25-meter digital elevation models of Slovenia relative to differences in surface heights, surface slopes, and surface aspects for all of Slovenia and for four areas with different relief. We compared the frequency of distribution, arithmetic mean, standard deviation, range, and coefficient of variation and tested the statistical significance of differences in the arithmetic means.

In comparing frequency of distribution, we established:

- the curves of frequency of distribution of surface heights for DEM-25 and DEM-100 overlap over almost their entire length;

- for surface slopes, the curve of DEM-100 for smaller surface slopes is larger and for greater surface slopes smaller than the curve of DEM-25; and

- for surface aspects, the path of the curve of DEM-25 is similar to the path of the curve of DEM-100, but is smoother with smaller oscillations.

In testing the arithmetic mean, we established the following:

- the difference between average surface height of DEM-25 and DEM-100 is not statistically significant for either all of Slovenia or the selected areas;

- the difference between average surface slope of DEM-25 and DEM-100 is statistically significant for all of Slovenia and for the selected areas; and

- the difference between average surface aspect of DEM-25 and DEM-100 is statistically significant for all of Slovenia and the Jeruzalem and Škocjan areas, but not for the Mount Škrlatica and Mirna River areas.

The comparison of statistical indicators showed the following:

- the difference between DEM-25 and DEM-100 relative to average surface height is smallest in the Škocjan area and largest in the Mount Škrlatica area, relative to average surface slope the difference is smallest in the Škocjan area and largest in the Mirna River area, and relative to average surface aspect it is smallest in the Mirna River area and largest in the Škocjan area;

- the difference between DEM-25 and DEM-100 relative to standard deviation of surface height is smallest in the Škocjan area and largest in the Jeruzalem area, relative to standard deviation of surface slope the difference is smallest in the Mount Škrlatica area and largest in the Mirna River and Škocjan areas, and relative to standard deviation of surface aspect the difference is smallest in the Mount Škrlatica area and largest in the Jeruzalem area;

- the difference between DEM-25 and DEM-100 relative to the coefficient of variation of surface height is smallest for all of Slovenia and largest in the Jeruzalem area, relative to the coefficient of variation of surface slope the difference is smallest in the Mount Škrlatica area and largest in the Škocjan area, and relative to the coefficient of variation of surface aspect is smallest for all of Slovenia and largest in the Škocjan area.

According to size classification of relief forms established by the French geomorphologist Tricart (1965), we can state that on DEM-100 presentations mezzo-relief and elementary relief forms are clearly visible 
and include mountain ridges, valleys, basins, and the like, while smaller relief forms including hillslope erosion gullies, river terraces, larger moraines, dolines, and some anthropogenic forms such as river embankments, quarries, and cultivated terraces are much more visible on DEM-25 presentations.

Our overall assessment is that DEM-100 can be used instead of DEM-25 for studying surface heights and the basic statistical indicators of smaller areas, for studying surface aspect in specific cases, and only exceptionally for studying surface slope. Compared with DEM-25, DEM-100 is distinctly weak in areas with distinct horizontal surface roughnes, which is the case for the majority of the hilly regions in Pannonian and Mediterranean Slovenia and for the low karst plateaus characteristic of Mediterranean and Dinaric Slovenia. The differences between DEM-100 and DEM-25 that we established using statistical indicators are further confirmed by graphical presentations of surface heights, surface slopes, and surface aspects (Figures 6 to 29).

\section{References}

Belec, B. 1968: Ljutomersko-ormoške gorice. Maribor.

Digitalni modeli višin (DMV). Medmrežje: http://www.gu.gov.si/gu/podatki/topograf/dmv/dmv.asp (5.11.2004)

Državna geodezija. Geodetska uprava Republike Slovenije. Ljubljana, 1998.

Eastman, J. R. 1995: IDRISI for Windows. User's Guide. Worcester.

Hrvatin, M., Perko, D. 2002: Ugotavljanje ukrivljenosti površja z digitalnim modelom višin in njena uporabnost v geomorfologiji. Geografski informacijski sistemi 2001-2002. Ljubljana.

Hrvatin, M., Perko, D. 2003: Gozdno rastje in morfometrične značilnosti površja v Sloveniji. Geografski vestnik 75-2. Ljubljana.

Kert, B. 1991: Regionalizacija Subpanonske Severovzhodne Slovenije. Dela 8. Ljubljana.

Mihelič, T. 2003: Julijske Alpe: planinski vodnik. Ljubljana.

Mihevc, A. 2001: Speleogeneza Divaškega krasa. Ljubljana.

Oštir, K., Podobnikar, T., Stančič, Z., Mlinar, J. 2000: Digitalni model višin Slovenije InSAR DMV 25. Geodetski vestnik 44-4. Ljubljana.

Perko, D. 2001: Analiza površja Slovenije s stometrskim digitalnim modelom reliefa. Geografija Slovenije 3. Ljubljana.

Perko, D. 2002: Določanje vodoravne in navpične razgibanosti površja z digitalnim modelom višin. Geografski vestnik 74-2. Ljubljana.

Podobnikar, T. 2002: Koncept izdelave novega digitalnega modela reliefa Slovenije. Geografski vestnik 74-1. Ljubljana.

Podobnikar, T. 2005: Production of Integrated Digital Terrain Model from multiple datasets of different quality. International Journal of Geographical Information Systems 19. London.

Podobnikar, T., Oštir, K. 1999: InSAR DMV 25. Ljubljana.

Rihtaršič, M., Fras, Z. 1991: Digitalni model reliefa. Ljubljana.

Topole, M. 1998: Mirnska dolina. Ljubljana.

Tricart, J. 1965: Principes et méthodes de la géomorphologie. Paris. 


\section{Razlike med stometrskim in petindvajsetmetrskim digitalnim modelom višin glede na tipe reliefa v Sloveniji}

UDK: 551.43:004.9(497.4)

COBISS: 1.01

IZVLEČEK: Pri preučevanju reliefa in pokrajine si pogosto pomagamo z digitalnimi modeli višin. Njihova uporabnost je povezana predvsem z njihovo natančnostjo. V članku primerjamo starejši, stometrski digitalni model višin in novejši, petindvajsetmetrski digitalni model višin Slovenije. Uporabnost ugotavljamo glede na razlike pri višinah, naklonih in ekspozicijah površja, in to za celotno Slovenijo ter za štiri reliefno različna območja. Primerjamo pogostnostno porazdelitev, aritmetično sredino, standardni odklon, variacijski razmik in koeficient variacije. Statistična analiza obeh digitalnih modelov višin Slovenije kaže, da so najmanjše razlike pri višinah, večje pri ekspozicijah in največje pri naklonih površja.

KLJUČNE BESEDE: relief, površje, digitalni model višin, višina, naklon, ekspozicija, Slovenija.

Uredništvo je prejelo prispevek 27. januarja 2005.

NASLOVA:

Mauro Hrvatin, univ. dipl. geogr.

Geografski inštitut Antona Melika

Znanstvenoraziskovalni center Slovenske akademije znanosti in umetosti

Gosposka ulica 13, SI - 1000 Ljubljana, Slovenija

E-pošta:mauro@zrc-sazu.si

\section{Drago Perko, dr.}

Geografski inštitut Antona Melika

Znanstvenoraziskovalni center Slovenske akademije znanosti in umetosti

Gosposka ulica 13, SI - 1000 Ljubljana, Slovenija

E-pošta:drago@zrc-sazu.si

\section{Vsebina}

1 Uvod 26

2 Izbrana območja $\quad 27$

3 Višina površja 28

4 Naklon površja 28

5 Ekspozicija površja 29

6 Sklep 32

$7 \quad$ Viri in literatura $\quad 32$ 


\section{Uvod}

Relief med vsemi sestavinami pokrajine največ prispeva k zunanji podobi slovenskih pokrajin (Hrvatin in Perko 2002, 2003). Pri sodobnih geografskih raziskavah je ob razcvetu geografskih informacijskih sistemov skoraj nepogrešljiv njegov navidezni prikaz, to je digitalni model višin.

Uporabnost digitalnih modelov višin za preučevanje reliefa in pokrajine je povezana predvsem z njihovo natančnostjo. V Sloveniji smo imeli do konca devetdesetih let 20. stoletja za območje celotne države na voljo le petstometrski in stometrski digitalni model višin. Oba slonita na točkah kvadratne mreže v Gauß-Krügerjevem koordinatnem sistemu (Rihtaršič in Fras 1991). Razumljivo je, da smo geografi pri raziskavah in kartografi pri tematskih zemljevidih od obeh modelov uporabljali predvsem natančnejši, stometrski digitalni model višin. Sestavljajo ga podatki o nadmorskih višinah točk, ki so od severa proti jugu oziroma vzhoda proti zahodu oddaljene $100 \mathrm{~m}$ in so oglišča kvadratnih celic z osnovnico $100 \mathrm{~m}$, diagonalo $141 \mathrm{~m}$ in površino 1 ha (Perko 2001).

Prav oddaljenost med točkami pa omejuje njegovo uporabnost, saj se reliefne oblike, ki niso precej večje od 100 oziroma $141 \mathrm{~m}$ povsem izgubijo ali pa vsaj bolj ali manj popačijo. To je še posebej pomembno pri preučevanju pokrajin s številnimi majhnimi reliefnimi oblikami, kakršne so značilne na primer za kraški relief, ki pokriva skoraj polovico Slovenije.

Leta 2000 smo na Znanstvenoraziskovalnem centru Slovenske akademije znanosti in umetnosti iz radarskih slik, ki jih je European space agency 'Evropska vesoljska agencija' posnela med letoma 1995 in 1999, za Geodetsko upravo Republike Slovenije izdelali petindvajsetmetrski digitalni model višin, tako imenovani interferometrični radarski digitalni model višin InSAR DMV 25 (Podobnikar in Oštir 1999; Oštir, Podobnikar, Stančič in Mlinar 2000; Podobnikar 2002; Podobnikar 2005). Sestavljajo ga podatki o nadmorskih višinah točk, ki so od severa proti jugu oziroma od vzhoda proti zahodu oddaljene $25 \mathrm{~m}$ in so oglišča kvadratnih celic z osnovnico $25 \mathrm{~m}$, diagonalo $35 \mathrm{~m}$ in površino $625 \mathrm{~m}^{2}$.

Testiranje je pokazalo, da je natančnost stometrskega digitalnega modela višin približno $10 \mathrm{~m}$ ( $3 \mathrm{~m}$ za ravnine in $16 \mathrm{~m}$ za gorovja), natančnost petindvajsetmetrskega digitalnega modela višin pa približno $5 \mathrm{~m}$ ( $2 \mathrm{~m}$ za ravnine in $14 \mathrm{~m}$ za gorovja); pri obeh so najbolj grobe napake v nekaj primerih v Alpah presegle $50 \mathrm{~m}$ (Državna geodezija 1998, Digitalni modeli višin 2004).

Razmerje med oddaljenostjo točk pri stometrskem in petindvajsetmetrskem digitalnem modelu višin je $4: 1$, med površino kvadratnih celic pa $16: 1$. V tem smislu je petindvajsetmetrski model višin šestnajstkrat bolj natančen od stometrskega.

Od treh temeljnih geometričnih lastnosti ploskev, ki jih v okviru geografskega informacijskega sistema lahko ugotavljamo z digitalnim modelom višin, to so oddaljenost, nagnjenost in ukrivljenost glede na vodoravno in navpično ravnino (Perko 2002), smo za primerjavo izbrali tri lastnosti oziroma kazalce, ki se najpogosteje uporabljajo v geografiji. To so:

- višina površja ali oddaljenost površja glede na vodoravno ravnino,

- naklon površja ali nagnjenost površja glede na vodoravno ravnino in

- ekspozicija površja ali nagnjenost površja glede na navpično ravnino.

Višine površja smo podali v metrih, naklone površja v stopinjah od 0 za ravno površje do 90 za navpično površje, ekspozicije površja pa v stopinjah od 0 za skrajno severno lego do 180 za skrajno južno lego. Izračunali smo jih za celotno Slovenijo in za štiri reliefno različna območja (pravokotne izseke) z dolžino $9 \mathrm{~km}$, širino $6 \mathrm{~km}$ in površino $54 \mathrm{~km}^{2}$. Za računanje kazalcev smo uporabili programski paket IDRISI (Eastman 1995).

Ugotovljeni kazalci pri stometrskem digitalnem modelu višin slonijo na 2.027.198 podatkih za Slovenijo in 5400 podatkih za posamezna območja, pri petindvajsetmetrskem digitalnem modelu višin pa na 32.436.693 podatkih za Slovenijo in 86.400 za posamezna območja. Območja (slika 1), ki smo poimenovali po gori Škrlatici v Julijskih Alpah, Savinem pritoku Mirni ter vaseh Jeruzalem v Slovenskih goricah in Škocjan blizu Škocjanskih jam, so na kratko opisana v drugem poglavju. 
Naslednja tri poglavja prikazujejo rezultate primerjav petindvajsetmetrskega in stometrskega digitalnega modela višin za Slovenijo in izbrana območja glede na višine, naklone in ekspozicije površja. Primerjamo pogostnostno porazdelitev, aritmetično sredino, standardni odklon, variacijski razmik (razlika med najvišjo in najnižjo vrednostjo) in koeficient variacije (razmerje med standardnim odklonom in aritmetično sredino) ter testiramo aritmetične sredine višin, naklonov in ekspozicij površja.

V nadaljnjem besedilu za stometrski digitalni model višin uporabljamo oznako DMV-100 in za petindvajsetmetrski digitalni model višin oznako DMV-25.

\section{Izbrana območja}

Območja, ki smo jih izbrali za primarjanje DMV-100 in DMV-25, se razlikujejo predvem glede na morfološki in genetski tip reliefa, navpično in vodoravno razgibanost površja ter kamninsko sestavo (slika 1).

Območje Škrlatice (slika 2) leži v severnem delu Vzhodnih Julijskih Alp. Obsega Škrlatiške in Martuljške gore, ki se dvigajo nad gozdno mejo in krepko presegajo 2000 m nadmorske višine. Mogočno gorsko skupino omejuje na severu dolina Save, na zahodu dolina Velike Pišnice in na vzhodu dolina Vrata. Gore so zgrajene večinoma iz karbonatnih kamnin, predvsem debelih plasti apnenca, doline pa zapolnjujejo ledeniški in rečni nanosi. V ledeniško močno preoblikovani pokrajini izstopajo prepadne stene, ki se od vršnih grebenov spuščajo v globoke krnice (Mihelič 2003). Za območje sta značilni velika navpična in majhna vodoravna razgibanost površja (Perko 2002).

Območje Mirne (slika 3) obsega hribovit in v manjši meri gričevnat svet spodnjega porečja reke Mirne med naseljem Tržišče in sotočjem s Savo. V tem delu je Mirna usmerjena prečno na slemena ob stiku Boštanjskega in Krškega hribovja. Reka je izdolbla globoko deber, posebej zanimivi so njeni ujeti okljuki. Rečno-denudacijsko površje, ki je zgrajeno večinoma iz lapornih in dolomitnih kamnin, je izredno razčlenjeno, slemena so močno razvejena, pobočja pa nerazgibana in brez grap (Topole 1998). Za območje sta značilni zmerna navpična in zmerna vodoravna razgibanost površja (Perko 2002).

Območje Jeruzalema (slika 4) obsega del Ljutomersko-Ormoških ali Vzhodnih Slovenskih goric. Njihovo ogrodje je lapornato in peščeno sleme med porečjema Ščavnice in Drave. Razvodno sleme poteka od vzhoda proti zahodu, številna stranska slemena pa so usmerjena predvsem proti severu in jugu (Kert 1991). V vododržne in erozijsko slabo odporne kamnine so potoki vrezali številne grape in dolinice, ki so zaradi skromnega strmca pogosto mokrotne. Na strmejših pobočjih se občasno prožijo usadi (Belec 1968). Za območje sta značilni zmerna navpična in velika vodoravna razgibanost površja (Perko 2002).

Območje Škocjana (slika 5) leži v jugovzhodnem delu Divaškega krasa v širši okolici Škocjanskih jam. Kraška planota je $\mathrm{v}$ grobem uravnana, $\mathrm{v}$ drobnem pa močno razčlenjena $\mathrm{z}$ vrtačami in globokimi udornicami, ki so nastale nad nekdanjim in zdajšnjim podzemnim tokom Reke. S severnih obronkov flišnih Brkinov priteka več potokov: nekateri se površinsko izlivajo v reko, drugi pa ponikajo v zatrepih slepih dolin. Slikovit kanjon in veliko slepo dolino je pred Škocjanskimi jamami izdelala tudi Reka (Mihevc 2001). Za območje sta značilni majhna navpična in zmerna vodoravna razgibanost površja (Perko 2002).

Slika 1: Lega izbranih območij na zemljevidu Slovenije.

Glej angleški del prispevka.

Slika 2: Gorska skupina Škrlatice (2740 m) v vzhodnem delu Julijskih Alp (fotografija: Miha Pavšek).

Glej angleški del prispevka.

Slika 3: Slikoviti ujeti okljuki Mirne v Krškem hribovju (fotografija: Marko Kapus).

Glej angleški del prispevka.

Slika 4: Slemena Jeruzalemskih goric pri Vinskem Vrhu (fotografija: Mimi Urbanc).

Glej angleški del prispevka.

Slika 5: Kraško površje z udornicami v okolici Škocjana (fotografija: Marjan Grbajs).

Glej angleški del prispevka. 


\section{Višina površja}

Krivulji pogostnostne porazdelitve nadmorskih višin DMV-25 in DMV-100 se tako pri Sloveniji kot izbranih območjih skoraj prek celotnega poteka prekrivata.

Povprečni nadmorski višini DMV-25 in DMV-100 se pri Sloveniji razlikujeta za samo 0,56 m, Škrlatici 2,46 m, Mirni 1,76 m, Jeruzalemu 0,83 m in Škocjanu 0,18 m, standardna odklona nadmorskih višin pa pri Sloveniji za 0,79 m, Škrlatici 1,64 m, Mirni 1,45 m, Jeruzalemu 1,95 m in Škocjanu 0,75 m. Koeficienta variacije nadmorskih višin DMV-25 in DMV-100 se pri Sloveniji razlikujeta za komaj 0,08 \% (odstotne točke), Škrlatici $0,15 \%$, Mirni $0,29 \%$, Jeruzalemu $0,73 \%$ in Škocjanu $0,15 \%$, njuno razmerje pa je pri Sloveniji 1,0012 ali 0,12\%, Škrlatici 1,0054 ali 0,54\%, Mirni 1,0110 ali 1,10\%, Jeruzalemu 1,0790 ali 7,90\% in Škocjanu 1,0105 ali 1,05\%.

Razumljivo je, da je variabilnost, izražena s koeficientom variacije, pri Sloveniji večja kot pri izbranih območjih, saj je variacijski razmik oziroma razpon nadmorskih višin v Sloveniji od 1 do $2816 \mathrm{~m}$ pri DMV-100 oziroma od 0,00 do 2851,80 m pri DMV-25, pri Jeruzalemu, kjer je razpon najmanjši, pa le od 208 do $332 \mathrm{~m}$ pri DMV-100 oziroma od 204,50 do 346,20 pri DMV-25.

V vseh primerih so razlike sorazmerno majhne, tako da za izračunavanje temeljnih statističnih kazalcev, kot so na primer aritmetična sredina, varianca, standardni odklon in koeficient variacije, zadostuje že uporaba DMV-100, in to tako za območje cele Slovenije kot za manjše izseke, kot so na primer naša izbrana območja.

To dokazuje tudi primerjanje povprečne nadmorske višine DMV-100 in DMV-25 s t-testom, ki je pokazalo, da tako pri Sloveniji kot pri izbranih območjih pri stopnji zaupanja $99 \%$ ni statistično pomembnih razlik.

Kakšne so razlike med DMV-100 in DMV-25, lahko ugotovimo tudi ob primerjavi grafičnih prikazov višin površja. Na primer, na prikazu območja Jeruzalema pri DMV-100 opazimo le potek in grobo izoblikovanost dolin in slemen (slika 18), pri DMV-25 pa tudi drobno razčlenjenost z erozijskimi žlebovi in grapami (slika 19).

\section{Naklon površja}

Krivulji pogostnostne porazdelitve naklonov DMV-25 in DMV-100 se pri Sloveniji in izbranih območjih bistveno razlikujeta. Pri Sloveniji do naklona $12^{\circ}$ sega višje krivulja DMV-100, od naklona $13^{\circ}$ pa krivulja DMV-25. Tudi pri vseh izbranih območjih je krivulja DMV-100 višja pri manjših naklonih in nižja pri večjih naklonih. To je razumljivo, saj natančnejši DMV-25 lahko ustrezneje prikaže razgibanost površja in s tem večje, ekstremnejše naklone. Na primer, pri Mirni je delež celic z naklonom $12^{\circ}$ pri DMV-100 $5,78 \%$ in pri DMV-25 samo 3,69\%, delež celic z naklonom $24^{\circ}$ pa pri DMV-100 le 0,85 \% in pri DMV-25 kar 3,10\%. V nekaterih primerih so torej razlike večkratne.

Povprečna naklona DMV-25 in DMV-100 se pri Sloveniji razlikujeta za 3,06 ${ }^{\circ}$, Škrlatici 2,81 ${ }^{\circ}$, Mirni 5,31 ${ }^{\circ}$, Jeruzalemu $3,38^{\circ}$ in Škocjanu $2,20^{\circ}$, standardna odklona naklonov pa pri Sloveniji za $1,83^{\circ}$, Škrlatici $1,38^{\circ}$, Mirni $2,11^{\circ}$, Jeruzalemu $2,08^{\circ}$ in Škocjanu $2,11^{\circ}$. Koeficienta variacije naklonov DMV-25 in DMV-100 se pri Sloveniji razlikujeta za 6,00 \% (odstotne točke), Škrlatici 1,05\%, Mirni 4,91 \%, Jeruzalemu 3,62 \% in Śkocjanu 6,12\%, njuno razmerje pa je pri Sloveniji 0,9319 ali 6,81 \%, Škrlatici 1,0291 ali 2,91 \%, Mirni 0,9118 ali 8,82 \%, Jeruzalemu 1,0706 ali 7,06 \% in Škocjanu 1,0857 ali 8,57\%.

Podobno kot pri višinah površja je tudi pri naklonih površja variabilnost pri Sloveniji večja kot pri izbranih območjih, saj je razpon naklonov v Sloveniji od 0,00 do $77,21^{\circ}$ pri DMV-100 oziroma od 0,00 do $89,24^{\circ}$ pri DMV-25, pri Jeruzalemu, kjer je razpon najmanjši, pa le od 0,00 do $18,15^{\circ}$ pri DMV-100 oziroma od 0,00 do $32,80^{\circ}$ pri DMV-25.

V vseh primerih so razlike med izračunanimi statističnimi kazalci tako velike, da je že pri Sloveniji priporočljiva uporaba DMV-25 namesto DMV-100, še bolj pa to velja pri manjših območjih. 
To dokazuje tudi primerjanje povprečnega naklona DMV-100 in DMV-25 s t-testom, ki je pokazalo, da so tako pri Sloveniji kot pri izbranih območjih pri stopnji zaupanja $99 \%$ statistično pomembne razlike.

Velike razlike med DMV-100 in DMV-25, ki smo jih ugotovili s statističnimi kazalci, potrjujejo tudi grafični prikazi naklonov površja. Na primer, na prikazu območja Mirne pri DMV-100 zaznamo le približno izoblikovanost pokrajine (slika 14), pri DMV-25 pa zaradi večje razlike med najmanjšimi in največjimi nakloni jasno vidimo tudi manjše oblike rečno-denudacijskega reliefa (slika 19), na primer rečne okljuke in večje ježe rečnih teras.

\section{Ekspozicija površja}

Krivulji pogostnostne porazdelitve ekspozicij DMV-25 in DMV-100 se pri Sloveniji in izbranih območjih razlikujeta bolj kot krivulji pogostnostne razporeditve nadmorskih višin, a precej manj kot krivulji pogostnostne porazdelitve naklonov. Potek krivulje ekspozicij DMV-25 je glede na potek krivulje ekspozicij DMV-100 podoben, vendar bolj umirjen, kar pomeni, da so deleži posameznih ekspozicij pri DMV-25 bolj izenačeni. To velja za Slovenijo in za vsa izbrana območja. Na primer, pri Sloveniji je delež celic s skrajno južno ekspozicijo $180^{\circ}$ pri DMV-100 kar 2,53\%, pri DMV-25 pa le $1,50 \%$. Pri obeh DMV je najmanjši delež celic z ekspozicijo $64^{\circ}$ : pri DMV-100 0,26\%, pri DMV-25 pa 0,40\%. Pri DMV-100 je razmerje med obema vrednostima skoraj 10, pri DMV-25 pa manj kot 4.

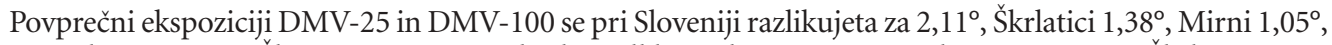
Jeruzalemu $2,20^{\circ}$ in Škocjanu $3,87^{\circ}$, standardna odklona ekspozicij pa pri Sloveniji za $1,24^{\circ}$, Škrlatici $0,18^{\circ}$, Mirni $0,89^{\circ}$, Jeruzalemu $1,37^{\circ}$ in Škocjanu $0,23^{\circ}$. Koeficienta variacije ekspozicij DMV-25 in DMV-100 se pri Sloveniji razlikujeta za 0,06 \% (odstotne točke), Škrlatici 1,20\%, Mirni 1,68 \%, Jeruzalemu 2,44\% in Śkocjanu 3,10\%, njuno razmerje pa je pri Sloveniji 0,9990 ali 0,10\%, Škrlatici 0,9805 ali 1,95\%, Mirni 0,9720 ali $2,80 \%$, Jeruzalemu 1,0540 ali 5,40 \% in Škocjanu 0,9507 ali 4,93\%.

V nasprotju z višinami in nakloni površja je variabilnost ekspozicij površja pri DMV-100 in DMV-25 pri vseh izbranih območjih, razen Jeruzalemu, rahlo večja kot pri Sloveniji, kar je prav tako razumljivo, saj je razpon ekspozicij površja tako pri Sloveniji kot pri vseh izbranih območjih med 0,00 in $180,00^{\circ}$, torej enak.

Čeprav so razlike med izračunanimi statističnimi kazalci manjše kot pri naklonih površja, je pri Sloveniji in manjših območjih priporočljiva uporaba DMV-25 namesto DMV-100, še posebej pri gričevnatih in kraško razčlenjenih območjih.

To potrjuje tudi primerjanje povprečne ekspozicije DMV-100 in DMV-25 s t-testom, ki je pokazalo, da so pri stopnji zaupanja 99 \% razlike pri Sloveniji, Jeruzalemu in Škocjanu statistično pomembne, pri Škrlatici in Mirni pa ne.

Razlike med ekspozicijami DMV-100 in DMV-25 so na grafičnih prikazih najbolj opazne pri manjših reliefnih oblikah. Na primer, na prikazu območja Škocjana pri DMV-100 skoraj ne moremo zaznati izoblikovanosti površja (slika 28), pri DMV-25 pa jasno vidimo drobno razčlenjenost kraškega površja $\mathrm{s}$ številnimi vrtačami in udornicami (slika 29).

Slika 6: Višine DMV-100 z vrednostmi od 703 m (najsvetlejši odtenek) do 2645 m (najtemnejši odtenek) za območje Škrlatice. Glej angleški del prispevka.

Slika 7: Višine DMV-25 z vrednostmi od 682,50 m (najsvetlejši odtenek) do 2718,90 m (najtemnejši odtenek) za območje Škrlatice. Glej angleški del prispevka.

Slika 8: Nakloni DMV-100 z vrednostmi od 0,64 (najsvetlejši odtenek) do 66,53 (najtemnejši odtenek) za območje Škrlatice. Glej angleški del prispevka.

Slika 9: Nakloni DMV-25 z vrednostmi od 0,00 (najsvetlejši odtenek) do 70,67 (najtemnejši odtenek) za območje Škrlatice. Glej angleški del prispevka. 
Slika 10: Ekspozicije DMV-100 z vrednostmi od 0,00 (najsvetlejši odtenek) do 180,00 (najtemnejši odtenek) za območje Škrlatice. Glej angleški del prispevka.

Slika 11: Ekspozicije DMV-25 z vrednostmi od 0,00 (najsvetlejši odtenek) do 180,00 (najtemnejši odtenek) za območje Škrlatice. Glej angleški del prispevka.

Slika 12: Višine DMV-100 z vrednostmi od 172 m (najsvetlejši odtenek) do 577 m (najtemnejši odtenek) za območje Mirne.

Glej angleški del prispevka.

Slika 13: Višine DMV-25 z vrednostmi od 168,60 m (najsvetlejši odtenek) do 589,60 m (najtemnejši odtenek) za območje Mirne.

Glej angleški del prispevka.

Slika 14: Nakloni DMV-100 z vrednostmi od 0,29 (najsvetlejši odtenek) do 38,49 (najtemnejši odtenek) za območje Mirne.

Glej angleški del prispevka.

Slika 15: Nakloni DMV-25 z vrednostmi od 0,00 (najsvetlejši odtenek) do 48,65 (najtemnejši odtenek) za območje Mirne.

Glej angleški del prispevka.

Slika 16: Ekspozicije DMV-100 z vrednostmi od 0,00 (najsvetlejši odtenek) do 180,00 (najtemnejši odtenek) za območje Mirne. Glej angleški del prispevka.

Slika 17: Ekspozicije DMV-25 z vrednostmi od 0,00 (najsvetlejši odtenek) do 180,00 (najtemnejši odtenek) za območje Mirne. Glej angleški del prispevka.

Slika 18: Višine DMV-100 z vrednostmi od 208 m (najsvetlejši odtenek) do 332 m (najtemnejši odtenek) za območje Jeruzalema. Glej angleški del prispevka.

Slika 19: Višine DMV-25 z vrednostmi od 204,50 m (najsvetlejši odtenek) do 346,20 m (najtemnejši odtenek) za območje Jeruzalema. Glej angleški del prispevka.

Slika 20: Nakloni DMV-100 z vrednostmi od 0,00 (najsvetlejši odtenek) do 18,15 (najtemnejši odtenek) za območje Jeruzalema. Glej angleški del prispevka.

Slika 21: Nakloni DMV-25 z vrednostmi od 0,00 (najsvetlejši odtenek) do 32,80 (najtemnejši odtenek) za območje Jeruzalema. Glej angleški del prispevka.

Slika 22: Ekspozicije DMV-100 z vrednostmi od 0,00 (najsvetlejši odtenek) do 180,00 (najtemnejši odtenek) za območje Jeruzalema. Glej angleški del prispevka.

Slika 23: Ekspozicije DMV-25 z vrednostmi od 0,00 (najsvetlejši odtenek) do 180,00 (najtemnejši odtenek) za območje Jeruzalema. Glej angleški del prispevka.

Slika 24: Višine DMV-100 z vrednostmi od 334 m (najsvetlejši odtenek) do 750 m (najtemnejši odtenek) za območje Škocjana. Glej angleški del prispevka.

Slika 25: Višine DMV-25 z vrednostmi od 315,40 m (najsvetlejši odtenek) do 770,40 m (najtemnejši odtenek) za območje Škocjana. Glej angleški del prispevka.

Slika 26: Nakloni DMV-100 z vrednostmi od 0,00 (najsvetlejši odtenek) do 29,80 (najtemnejši odtenek) za območje Škocjana. Glej angleški del prispevka.

Slika 27: Nakloni DMV-25 z vrednostmi od 0,00 (najsvetlejši odtenek) do 52,82 (najtemnejši odtenek) za območje Škocjana. Glej angleški del prispevka.

Slika 28: Ekspozicije DMV-100 z vrednostmi od 0,00 (najsvetlejši odtenek) do 180,00 (najtemnejši odtenek) za območje Škocjana. Glej angleški del prispevka.

Slika 29: Ekspozicije DMV-25 z vrednostmi od 0,00 (najsvetlejši odtenek) do 180,00 (najtemnejši odtenek) za območje Škocjana. Glej angleški del prispevka. 


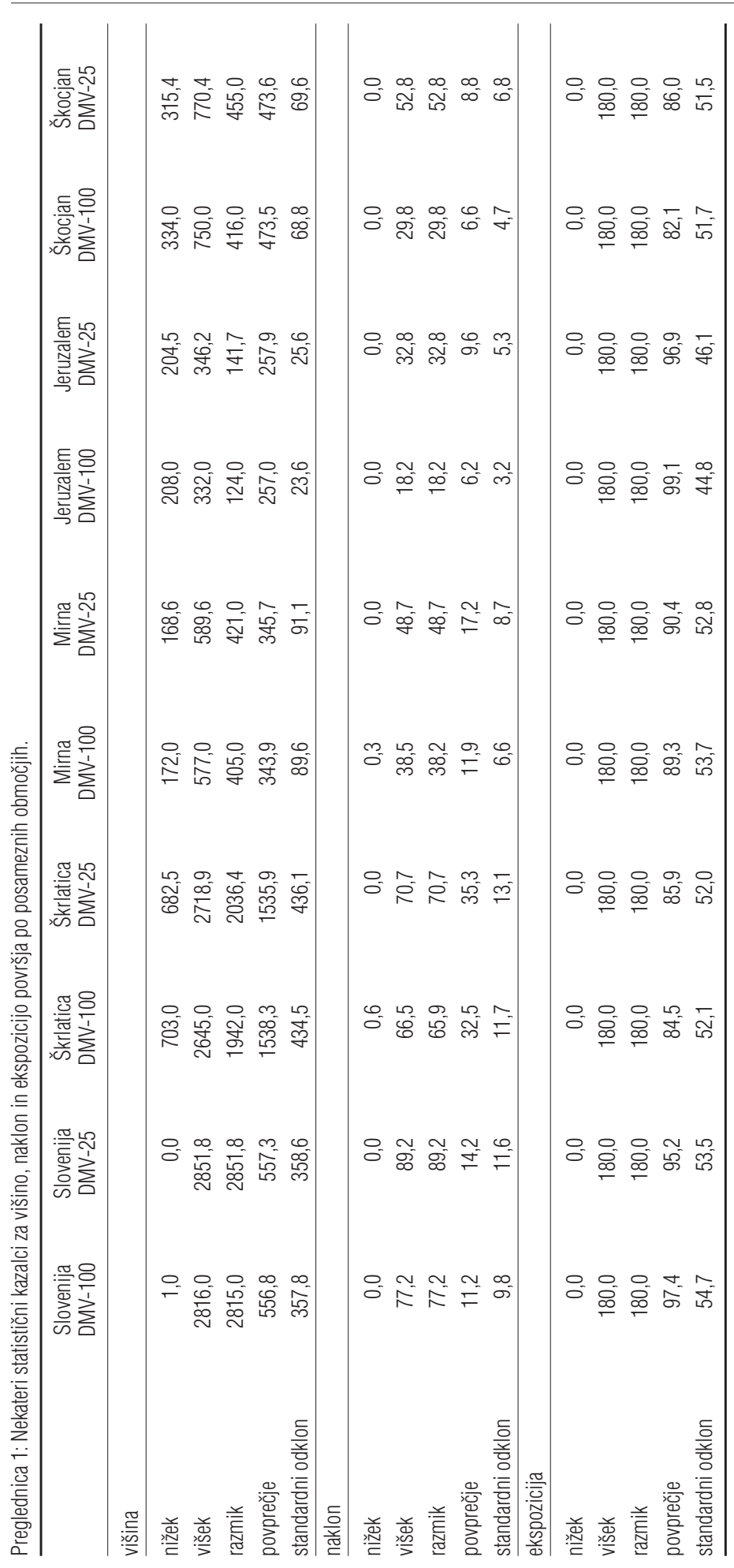




\section{Sklep}

Preučevanje reliefa in pokrajine s pomočjo digitalnih modelov višin je povezano predvsem z njihovo natančnostjo. V članku smo obravnavali stometrski in petindvajsetmetrski digitalni model višin Slovenije glede na razlike pri višinah, naklonih in ekspozicijah površja za Slovenijo in štiri reliefno različna območja. Primerjali smo pogostnostno porazdelitev, aritmetično sredino, standardni odklon, variacijski razmik in koeficient variacije ter testirali statistično pomembnost razlik aritmetičnih sredin.

Pri primerjavi pogostnostnih porazdelitev smo ugotovili:

- krivulji pogostnostne porazdelitve nadmorskih višin DMV-25 in DMV-100 se skoraj prek celotnega poteka prekrivata,

- pri naklonih je krivulja DMV-100 pri manjših naklonih višja, pri večjih naklonih pa nižja od krivulje DMV-25,

- pri ekspozicijah pa je potek krivulje DMV-25 podoben poteku krivulje DMV-100, a bolj umirjen, z manjšimi nihanji.

Pri testiranju aritmetične sredine smo ugotovili:

- razlika med povprečno nadmorsko višino DMV-25 in DMV-100 ni statistično pomembna niti pri Sloveniji niti pri izbranih območjih,

- razlika med povprečnim naklonom DMV-25 in DMV-100 je statistično pomembna tako pri Sloveniji kot pri vseh izbranih območjih,

- razlika med povprečno ekspozicijo DMV-25 in DMV-100 je statistično pomembna pri Sloveniji, Jeruzalemu in Škocjanu, pri Škrlatici in Mirni pa ne.

Primerjava statističnih kazalcev je pokazala:

- razlika med DMV-25 in DMV-100 je pri povprečni višini površja najmanjša pri Škocjanu in največja pri Škrlatici, pri povprečnem naklonu površja najmanjša pri Škocjanu in največja pri Mirni, pri povprečni ekspoziciji površja pa najmanjša pri Mirni in največja pri Škocjanu.

- razlika med DMV-25 in DMV-100 je pri standardnem odklonu višine površja najmanjša pri Škocjanu in največja pri Jeruzalemu, pri standardnem odklonu naklona površja najmanjša pri Škrlatici in največja pri Mirni in Škocjanu, pri standardnem odklonu ekspozicije površja pa najmanjša pri Škrlatici in največja pri Jeruzalemu,

- razlika med DMV-25 in DMV-100 je pri koeficientu variacije višine površja najmanjša pri Sloveniji in največja pri Jeruzalemu, pri koeficientu variacije naklona površja najmanjša pri Škrlatici in največja pri Škocjanu, pri koeficientu variacije ekspozicije površja pa najmanjša pri Sloveniji in največja pri Škocjanu.

Glede na velikostno klasifikacijo reliefnih oblik, ki jo je opravil francoski geomorfolog Tricart (1965), lahko ugotovimo, da so na prikazih DMV-100 dobro vidne mezoreliefne in elementarne reliefne oblike, med katere na primer uvrščamo gorske hrbte, doline, kotline in podobno, manjše reliefne oblike, med katere spadajo pobočni erozijski žlebovi, rečne terase, večji morenski nasipi, vrtače ter nekatere antropogene oblike, na primer obrečni nasipi, izkopi kamnolomov in obdelovalne terase, pa se veliko jasneje kažejo na prikazih DMV-25.

Splošna ocena je, da DMV-100 pri višinah površja lahko tudi pri manjših območjih pri temeljnih statističnih kazalcih nadomesti DMV-25, pri ekspozicijah površja v določenih primerih, pri naklonih površja pa le izjemoma. DMV-100 je glede na DMV-25 izrazito slab pri območjih z izrazito vodoravno razgibanostjo površja, kakršna je večina slovenskih gričevij v panonski in sredozemski Sloveniji in nizkih kraških planot v sredozemski in dinarski Sloveniji. Razlike med DMV-100 in DMV-25, ki smo jih ugotovili s statističnimi kazalci, potrjujejo tudi grafični prikazi višin, naklonov in ekspozicij površja (slike 6 do 29).

\section{Literatura in viri}

Glej angleški del prispevka. 